Supplementary Information

\title{
Selective Ethane/Ethylene Separation in a Robust Microporous Hydrogen-Bonded Organic Framework
}

Xu Zhang, ${ }^{1, t}$ Libo Li, ${ }^{\text {s. }}$ Jia-Xin Wang, ${ }^{\dagger}$ Hui-Min Wen, ${ }^{\perp}$ Rajamani Krishna, ${ }^{\#}$ Hui Wu, ${ }^{\nabla}$ Wei Zhou, ${ }^{\nabla}$ Zhong-Ning Chen, ${ }^{*}$ Bin Li, ${ }^{* \dagger}$ Guodong Qian, ${ }^{\dagger}$ and Banglin Chen ${ }^{*} \|$

${ }^{\dagger}$ State Key Laboratory of Silicon Materials, School of Materials Science and Engineering, Zhejiang University, Hangzhou 310027, China

${ }^{\sharp}$ State Key Laboratory of Structural Chemistry, Fujian Institute of Research on the Structure of Matter, Chinese Academy of Sciences, Fuzhou, Fujian 350002, China.

${ }^{\S}$ College of Chemistry and Chemical Engineering, Taiyuan University of Technology, Taiyuan 030024, Shanxi, P. R. China

Department of Chemistry, University of Texas at San Antonio, One UTS A Circle, San Antonio, TX 78249-0698, United States

${ }^{\perp}$ College of Chemical Engineering, Zhejiang University of Technology, Zhejiang, 310014, P. R. China

\# Van 't Ho ff Institute for Molecular Sciences, University of Amsterdam, Science Park 904, 1098 XH Amsterdam, The Netherlands

$\nabla$ NIST Center for Neutron Research, National Institute of Standards and Technology, Gaithersburg, MD 20899-6102, United States 


\section{General materials and procedures}

All starting chemicals and solvents were purchased from commercial companies and used without further purification: hexabromobenzene (Alfa Aesar, 97\%); ethyl 4-ethynylbenzoate was prepared from 4-Bromobenzoic acid (Alfa Aesar, 98+\%); $\mathrm{Pd}\left(\mathrm{PPh}_{3}\right)_{2} \mathrm{Cl}_{2}$ (Aladdin, 98+\%); CuI (Acros, 98\%); $\mathrm{PPh}_{3}$ (Greagent, 99+\%); trimethylsilylacetylene (Macklin, 98+\%); $\mathrm{D}_{2} \mathrm{O}$ (SigmaAlderich, 99.9 atom\%); $\mathrm{NaOD}$ (Norell, $30 \mathrm{WT} \%$ in $\mathrm{D}_{2} \mathrm{O}, 99.9$ atom\%); DCl (Sigma-Alderich, 35 WT\% in $\mathrm{D}_{2} \mathrm{O}, 99+$ atom\%). ${ }^{1} \mathrm{H}$ and ${ }^{13} \mathrm{C}$ NMR spectra were recorded on Bruker AVANCE III spectrometers (400 MHz). Thermogravimetric analyses (TGA) were performed on a Netzsch STA 449C thermal analyzer from 30 to $800{ }^{\circ} \mathrm{C}$ under nitrogen atmosphere at a heating rate of $5{ }^{\circ} \mathrm{C} /$ minute rate. Powder X-ray diffraction (PXRD) patterns were measured by a BRUKER D8 ADVANCE diffractometer employing $\mathrm{Cu}-\mathrm{K}_{\alpha}$ radiation operated at $30 \mathrm{kV}$ and $15 \mathrm{~mA}$, scanning over the range $2-45^{\circ}(2 \theta)$ at a rate of $2 \% \mathrm{~min}$.

$\mathrm{C}_{2} \mathrm{H}_{4}(99.99 \%), \mathrm{C}_{2} \mathrm{H}_{6}(99.99 \%)$, He (99.999\%) and mixed gases of $\mathrm{C}_{2} \mathrm{H}_{4} / \mathrm{C}_{2} \mathrm{H}_{6}=10 / 90(\mathrm{v} / \mathrm{v})$, $\mathrm{C}_{2} \mathrm{H}_{4} / \mathrm{C}_{2} \mathrm{H}_{6}=50 / 50(\mathrm{v} / \mathrm{v})$, and $\mathrm{C}_{2} \mathrm{H}_{6} / \mathrm{C}_{2} \mathrm{H}_{4} / \mathrm{C}_{2} \mathrm{H}_{2} / \mathrm{CH}_{4} / \mathrm{H}_{2}(10 / 87 / 1 / 1 / 1)$ mixtures were purchased from Beijing Special Gas Co. LTD (China).

\section{Fitting of pure component isotherms}

The pure component isotherm data for $\mathrm{C}_{2} \mathrm{H}_{4}$ and $\mathrm{C}_{2} \mathrm{H}_{6}$ in $\mathrm{HOF}-76$ were measured at $273 \mathrm{~K}$ and 296 K. The data were fitted with the 1-site Langmuir-Freundlich model

$$
q=q_{\text {sat }} \frac{b p^{v}}{1+b p^{v}}
$$

The parameter $\mathrm{b}$ is temperature dependent

$$
b=b_{0} \exp (E / R T)
$$

The fitted parameter values are provided in Table S1-S2 and Figure S27.

\section{Isosteric heat of adsorption}

The binding energy is reflected in the isosteric heat of adsorption, $Q_{\mathrm{st}}$, defined as 


$$
Q_{s t}=R T^{2}\left(\frac{\partial \ln p}{\partial T}\right)_{q}
$$

The $Q_{\text {st }}$ values as function of the molar loadings are provided in Figure S16.

\section{IAST calculations of adsorption selectivities}

The selectivity of preferential adsorption of component $1\left(\mathrm{C}_{2} \mathrm{H}_{6}\right)$ over component $2\left(\mathrm{C}_{2} \mathrm{H}_{4}\right)$ can be defined as

$$
S_{a d s}=\frac{q_{1} / q_{2}}{p_{1} / p_{2}}
$$

Where $q_{1}$ and $q_{2}$ are the absolute component loadings of the adsorbed phase in the mixture, and $p_{1}$ and $p_{2}$ are the component partial pressures. The component loadings and adsorption selectivity $S_{\text {ads }}$ for $50 / 50 \mathrm{C}_{2} \mathrm{H}_{6}(1) / \mathrm{C}_{2} \mathrm{H}_{4}(2)$ and $10 / 90 \mathrm{C}_{2} \mathrm{H}_{6}(1) / \mathrm{C}_{2} \mathrm{H}_{4}(2)$ mixtures in HOF-76a at $296 \mathrm{~K}$ were determined using IAST.

\section{Breakthrough simulations}

The performance of industrial fixed bed adsorbers is dictated by a combination of adsorption selectivity and uptake capacity. Transient breakthrough simulations were carried out for 50/50 $\mathrm{C}_{2} \mathrm{H}_{6}(1) / \mathrm{C}_{2} \mathrm{H}_{4}(2)$ and $10 / 90 \mathrm{C}_{2} \mathrm{H}_{6}(1) / \mathrm{C}_{2} \mathrm{H}_{4}(2)$ mixtures in HOF-76 operating at $298 \mathrm{~K}$ and a total pressure of 1 bar or 5 bar respectively, using the methodology described in earlier publications. ${ }^{1,2}$ For the breakthrough simulations, the following parameter values were used: length of packed bed, $L=0.3 \mathrm{~m}$; voidage of packed bed, $\varepsilon=0.4$; superficial gas velocity at inlet, $u=0.04 \mathrm{~m} / \mathrm{s}$. The transient breakthrough simulation results are presented in terms of a dimensionless time, $\tau=\frac{t u}{L \varepsilon}$, defined by dividing the actual time, $t$, by the characteristic time, $\frac{L \varepsilon}{u}$.

The breakthrough simulations demonstrate the potential of producing product gas $\mathrm{C}_{2} \mathrm{H}_{4}$ of required purity during the interval $\Delta \tau$.

\section{Stability studies}


To investigate the chemical stabilities of HOF-76, the as-synthesized samples were soaked in water, $\mathrm{HCl}(\mathrm{pH}=1)$ and $\mathrm{NaOH}(\mathrm{pH}=10)$ solutions for 24 hours, respectively. After that, each sample was filtered and washed with water and acetone quickly, and then characterized by PXRD measurements in order to determine whether the sample retains its structural integrity. Subsequently, each sample was solvent-exchanged with dry acetone at least 8 times within two days to completely remove the hardly volatile $\mathrm{H}_{2} \mathrm{O}$ molecules in the pores, and then was activated by the activation conditions prior to gas sorption measurements. The $77 \mathrm{~K} \mathrm{~N}_{2}$ and 296 $\mathrm{K} \mathrm{C}_{2} \mathrm{H}_{6}$ sorption isotherms were examined to further determine the chemical stability of HOF- 76 . The thermal stability of HOF-76 was studied by thermogravimetric analysis and various temperature PXRD patterns. The sample for temperature PXRD patterns was treated with $100^{\circ}$, $150^{\circ}, 200^{\circ}, 300^{\circ}$ for 2 hours, respectively, and then characterized by PXRD measurements. To further check the thermal stability, the sample treated with $300^{\circ}$ was solvent-exchanged by dry acetone and then activated to examine the $77 \mathrm{~K} \mathrm{~N}_{2}$ and $296 \mathrm{~K} \mathrm{C}_{2} \mathrm{H}_{6}$ sorption isotherms.

To further confirm its ultrahigh chemical stability in acid and base solutions, the samples were also soaked into $\mathrm{pH}=10 \mathrm{NaOD}$ solution $\left(0.01 \mathrm{~mol} / \mathrm{L} \mathrm{NaOD}\right.$ in $\mathrm{D}_{2} \mathrm{O}$ solution) and $\mathrm{pH}=1$ $\mathrm{HCl}$ solution (0.1 mol/L DCl in $\mathrm{D}_{2} \mathrm{O}$ solution), respectively. After 24 hours, the $\mathrm{D}_{2} \mathrm{O}$ solution was directly used to measure ${ }^{1} \mathrm{H}$ NMR spectra. As shown in Figure S11, there is no any signal of HCEB ligand observed, strongly demonstrating that the HOF-76 framework remains stable in these acid and base solutions and no ligands are dissociated into the $\mathrm{D}_{2} \mathrm{O}$ solution.

Considering that the $\mathrm{C}_{2} \mathrm{H}_{4}$ feed gas in industry is often contaminated by trace levels of $\mathrm{H}_{2} \mathrm{O}(5$ $50 \mathrm{ppm}$ ), the effect of moisture on breakthrough experiments was carried out on HOF-76a for $50 / 50 \mathrm{C}_{2} \mathrm{H}_{6} / \mathrm{C}_{2} \mathrm{H}_{4}$ mixtures containing trace $\mathrm{H}_{2} \mathrm{O}$ (from 446 to $2130 \mathrm{ppm}$ ) that are more extreme than that found in a realistic process. Figure S24 showed that the presence of trace $\mathrm{H}_{2} \mathrm{O}$ has a negligible effect on the breakthrough performance of HOF-76a. 


\section{Notation}

$\begin{array}{ll}b & \text { Langmuir-Freundlich constant, } \mathrm{Pa}^{-v} \\ q & \text { component molar loading of species } i, \mathrm{~mol} \mathrm{~kg}^{-1} \\ q_{\mathrm{sat}} & \text { saturation loading, mol kg-1 } \\ L & \text { length of packed bed adsorber, } \mathrm{m} \\ t & \text { time, } \mathrm{s} \\ T & \text { absolute temperature, } \mathrm{K} \\ u & \text { superficial gas velocity in packed bed, } \mathrm{m} \mathrm{s}^{-1}\end{array}$

\section{Greek letters}

$\varepsilon \quad$ voidage of packed bed, dimensionless

$v \quad$ Freundlich exponent, dimensionless

$\tau \quad$ time, dimensionless 
Table S1. 1-site Langmuir-Freundlich parameter fits for $\mathrm{C}_{2} \mathrm{H}_{4}$ and $\mathrm{C}_{2} \mathrm{H}_{6}$ in $\mathrm{HOF}-76$ at 1 bar and room temperature.

\begin{tabular}{|l|l|l|l|l|}
\hline & $\begin{array}{l}q_{\mathrm{sat}} \\
\mathrm{mol} \mathrm{kg}\end{array}$ & $\begin{array}{l}b_{0} \\
\mathrm{~Pa}^{-v}\end{array}$ & $\begin{array}{l}E \\
\mathrm{~kJ} \mathrm{~mol}^{-1}\end{array}$ & \begin{tabular}{l} 
dimensionless \\
\hline $\mathrm{C}_{2} \mathrm{H}_{4}$
\end{tabular} \\
\hline $\mathrm{C}_{2} \mathrm{H}_{6}$ & 6.3 & $5.25 \mathrm{E}-13$ & 35 & 1.14 \\
\hline
\end{tabular}

Table S2. 1-site Langmuir-Freundlich parameter fits for $\mathrm{C}_{2} \mathrm{H}_{4}$ and $\mathrm{C}_{2} \mathrm{H}_{6}$ in $\mathrm{HOF}-76$ at 5 bar and $298 \mathrm{~K}$.

\begin{tabular}{|l|l|l|l|}
\hline & $\begin{array}{l}q_{\text {sat }} \\
\mathrm{mol} \mathrm{kg}^{-1}\end{array}$ & $\begin{array}{l}\text { Pa } \\
\mathrm{Pa}^{-1}\end{array}$ & \\
\hline $\mathrm{C}_{2} \mathrm{H}_{4}$ & 11.9 & $1.73674 \mathrm{E}-06$ & 0.9953 \\
\hline $\mathrm{C}_{2} \mathrm{H}_{6}$ & 9 & $4.846 \mathrm{E}-06$ & 0.9857 \\
\hline
\end{tabular}


Table S3. Crystallographic data and structure refinement results of HOF-76.

\begin{tabular}{|c|c|}
\hline & HOF-76 \\
\hline Formula & $\mathrm{C}_{60} \mathrm{H}_{30} \mathrm{O}_{12}$ \\
\hline Formula weight & 942.84 \\
\hline Temperature/K & $100(2)$ \\
\hline Crystal system & Monoc linic \\
\hline Space group & $C 2 / \mathrm{c}$ \\
\hline$a, b(\AA)$ & $22.539(3), 40.639(5)$ \\
\hline$c(\AA)$ & $13.7223(17)$ \\
\hline$\alpha\left(^{\circ}\right)$ & 90.00 \\
\hline$\beta\left({ }^{\circ}\right)$ & $96.088(5)$ \\
\hline$\gamma\left({ }^{\circ}\right)$ & 90.00 \\
\hline$V\left(\AA^{3}\right)$ & $12498(3)$ \\
\hline$Z$ & 8 \\
\hline$D_{\text {calcd }}\left(\mathrm{g} \mathrm{cm}^{-3}\right)$ & 1.002 \\
\hline$\mu\left(\mathrm{mm}^{-1}\right)$ & 0.070 \\
\hline$F(000)$ & 3888.0 \\
\hline Crystal size $/ \mathrm{mm}^{3}$ & $0.0032 \times 0.0028 \times 0.0028$ \\
\hline GOF & 1.005 \\
\hline$R_{\text {int }}$ & 0.1562 \\
\hline$R_{1}, w R_{2}[\mathrm{I}>=2 \sigma(\mathrm{I})]$ & $0.0772,0.2123$ \\
\hline$R_{1}, w R_{2}$ [all data] & $0.1799,0.2684$ \\
\hline CCDC number & 1907797 \\
\hline
\end{tabular}

${ }^{a} \mathrm{R} 1=\Sigma\left|F_{\mathrm{o}}-F_{\mathrm{c}}\right| / \Sigma F_{\mathrm{o}},{ }^{b} w \mathrm{R} 2=\Sigma\left[w\left(F_{\mathrm{o}}{ }^{2}-F_{\mathrm{c}}{ }^{2}{ }^{2}\right] / \Sigma\left[w\left(F_{\mathrm{o}}\right)^{2}\right)\right]^{1 / 2}$ 
Table S4. Comparison of the density and features of H-bonds, the distance of $\pi \cdots \pi$ interactions, and the surface area in HOF-76 and some selected carboxylic acid-type HOFs with established porosities.

\begin{tabular}{|c|c|c|c|c|c|c|c|}
\hline $\begin{array}{c}\text { carboxylic } \\
\text { acid-type } \\
\text { HOFs }\end{array}$ & $\begin{array}{c}\text { Number of } \\
\text { carboxylic } \\
\text { acids }\end{array}$ & $\begin{array}{c}\text { Density of } \\
\text { H-bonds } \\
\left(\mathrm{mmol} / \mathrm{cm}^{3}\right)\end{array}$ & $\begin{array}{c}\mathrm{d}_{\mathrm{O}-\mathrm{H} \cdots \mathrm{O}} \\
(\AA)^{a}\end{array}$ & $\begin{array}{l}\text { Angel of } \\
\mathrm{O}-\mathrm{H} \cdots \mathrm{O} \\
\text { bonds }^{b}\end{array}$ & $\begin{array}{c}\mathrm{d}_{\pi \cdots \pi} \text { stacking } \\
(\AA)^{c}\end{array}$ & $\begin{array}{c}\mathrm{S}_{\mathrm{BET}} \\
\left(\mathrm{m}^{2} \mathrm{~g}^{-1}\right)^{d}\end{array}$ & Ref. \\
\hline HOF-76 & 6 & 6.276 & 2.622 & 171.2 & 3.352 & 1121 & This work \\
\hline HOF-TCBP & 4 & 4.355 & 2.620 & 176.3 & 3.425 & 2066 & [3] \\
\hline PFC-1 & 4 & 4.342 & 2.597 & 176.0 & 3.338 & 2122 & [4] \\
\hline Ex-1 & 6 & 3.120 & $2.551-2.697$ & 170.4 & 3.446 & - & [5] \\
\hline $\mathrm{T} 12-1$ & 6 & 5.765 & $2.565-2.816$ & 173.8 & 3.459 & 557 & [5] \\
\hline PETHOF-1a & 6 & 0.994 & 2.580 & 161.8 & - & 1140 & [6] \\
\hline PETHOF-2a & 6 & 2.553 & 2.600 & 160.6 & 3.30 & 1690 & [6] \\
\hline HOF-BTB & 3 & 3.254 & 2.594 & 166.4 & - & 955 & [7] \\
\hline $\begin{array}{l}\text { IISERP- } \\
\text { HOF1 }\end{array}$ & 3 & 4.067 & 2.592 & 165.2 & - & 1025 & {$[8]$} \\
\hline TCF-1 & 4 & 4.995 & 2.823 & 152.6 & 3.600 & - & [9] \\
\hline
\end{tabular}


Table S5. Summary of separation metrics of top-performing ethane-selective materials reported in the literature at 1 bar and room temperature (RT).

\begin{tabular}{|c|c|c|c|c|c|c|c|}
\hline $\begin{array}{c}\mathrm{C}_{2} \mathrm{H}_{6} \text {-selective } \\
\text { adsorbents }\end{array}$ & $\begin{array}{c}\mathrm{C}_{2} \mathrm{H}_{6} \text { uptake }{ }^{a} \\
(\mathrm{mmol} / \mathrm{g})\end{array}$ & $\begin{array}{c}\mathrm{C}_{2} \mathrm{H}_{4} \text { uptake }^{a} \\
(\mathrm{mmol} / \mathrm{g})\end{array}$ & $\begin{array}{c}\text { Uptake ratio }^{b} \\
(\%)\end{array}$ & Selectivity $^{c}$ & $\begin{array}{l}Q_{s t, \text { ethane }} \\
(\mathrm{kJ} / \mathrm{mol})^{d}\end{array}$ & $\begin{array}{c}\text { Productivity }_{\text {exp }} \\
(\mathrm{L} / \mathrm{kg})^{e}\end{array}$ & Ref. \\
\hline HOF-76a & 2.95 & 1.67 & 177 & 2.05 & 22.8 & $7.2 / 18.8^{f}$ & $\begin{array}{l}\text { This } \\
\text { work }\end{array}$ \\
\hline $\mathrm{Fe}_{2} \mathrm{O}_{2}$ (dobdc) & 3.32 & 2.53 & 131 & 4.4 & 66.8 & 19.3 & {$[10]$} \\
\hline MUF-15 & $4.69^{c}$ & $4.15^{c}$ & $113^{c}$ & $1.94^{c}$ & 29.2 & 14 & [11] \\
\hline MAF-49 & 1.73 & 1.69 & 102 & 2.7 & 61 & 6.2 & {$[12]$} \\
\hline $\mathrm{Cu}(\mathrm{Qc})_{2}$ & 1.85 & 0.78 & 235 & 3.4 & 29 & 4.4 & {$[13]$} \\
\hline UiO- $66-2 \mathrm{CF}_{3}$ & 0.86 & 0.50 & 171 & 2.5 & 30 & - & [14] \\
\hline PCN-250 & 5.20 & 4.22 & 123 & 1.9 & 23.2 & 3.36 & {$[15]$} \\
\hline UiO-66 & 2.38 & 1.72 & 138 & 1.8 & - & - & [14] \\
\hline UiO-66-NDC & 4.3 & 3.46 & 124 & 1.4 & - & - & [14] \\
\hline PCN-245 & 3.27 & 2.39 & 137 & 1.9 & 22.8 & 5.8 & [16] \\
\hline$\left[\mathrm{Ni}(\mathrm{bdc})(\mathrm{ted})_{0.5}\right.$ & 5.0 & 3.4 & 147 & 1.6 & 21.5 & - & [17] \\
\hline MIL-53(Al) & $2.16^{g}$ & $1.72^{g}$ & 126 & 1.6 & 22.5 & - & {$[18]$} \\
\hline MIL-142(A) & 3.8 & 2.9 & 131 & 1.5 & - & - & [14] \\
\hline IR-MOF-8 & 4.3 & 3.0 & 143 & 1.8 & 52.5 & 2.5 & [19] \\
\hline ZIF- $8^{h}$ & 2.52 & 1.51 & 167 & 1.7 & 17.2 & 0.4 & [20] \\
\hline ZIF-7 & 1.83 & 1.80 & 102 & 1.5 & - & 2 & [21] \\
\hline ZIF-4 ${ }^{h}$ & 2.30 & 2.20 & 104 & 2.15 & - & 6.6 & [22] \\
\hline UTSA-35 & 2.43 & 2.16 & 112 & 1.4 & - & - & [10] \\
\hline HOF-BTB $^{i}$ & 3.09 & 2.48 & 124 & 1.4 & 25.4 & - & [23] \\
\hline
\end{tabular}

\footnotetext{
${ }^{a}$ At 1 bar and room temperature; ${ }^{b} \mathrm{C}_{2} \mathrm{H}_{6} / \mathrm{C}_{2} \mathrm{H}_{4}$ uptake ratio at 1 bar and RT; ${ }^{c}$ IAST selectivity for $50 / 50 \mathrm{C}_{2} \mathrm{H}_{6} / \mathrm{C}_{2} \mathrm{H}_{4}$ gas mixtures;

${ }^{d}$ The adsorption heat $\left(Q_{\mathrm{st}}\right)$ of $\mathrm{C}_{2} \mathrm{H}_{6}$ at low surface coverage. ${ }^{e}$ The pure $\mathrm{C}_{2} \mathrm{H}_{4}$ productivity calculated from breakthrough experiments at 1 bar and RT on 50/50 gas mixtures. ${ }^{f}$ The pure $\mathrm{C}_{2} \mathrm{H}_{4}$ productivity under 5.0 bar and RT. ${ }^{g}$ At $323 \mathrm{~K} .{ }^{h}$ At $293 \mathrm{~K} .{ }^{i}$ The reported literature only described the $\mathrm{C}_{2} \mathrm{H}_{4}$ and $\mathrm{C}_{2} \mathrm{H}_{6}$ adsorption isotherms, so the selectivity and uptake ratio were evaluated based on these isotherms.
} 


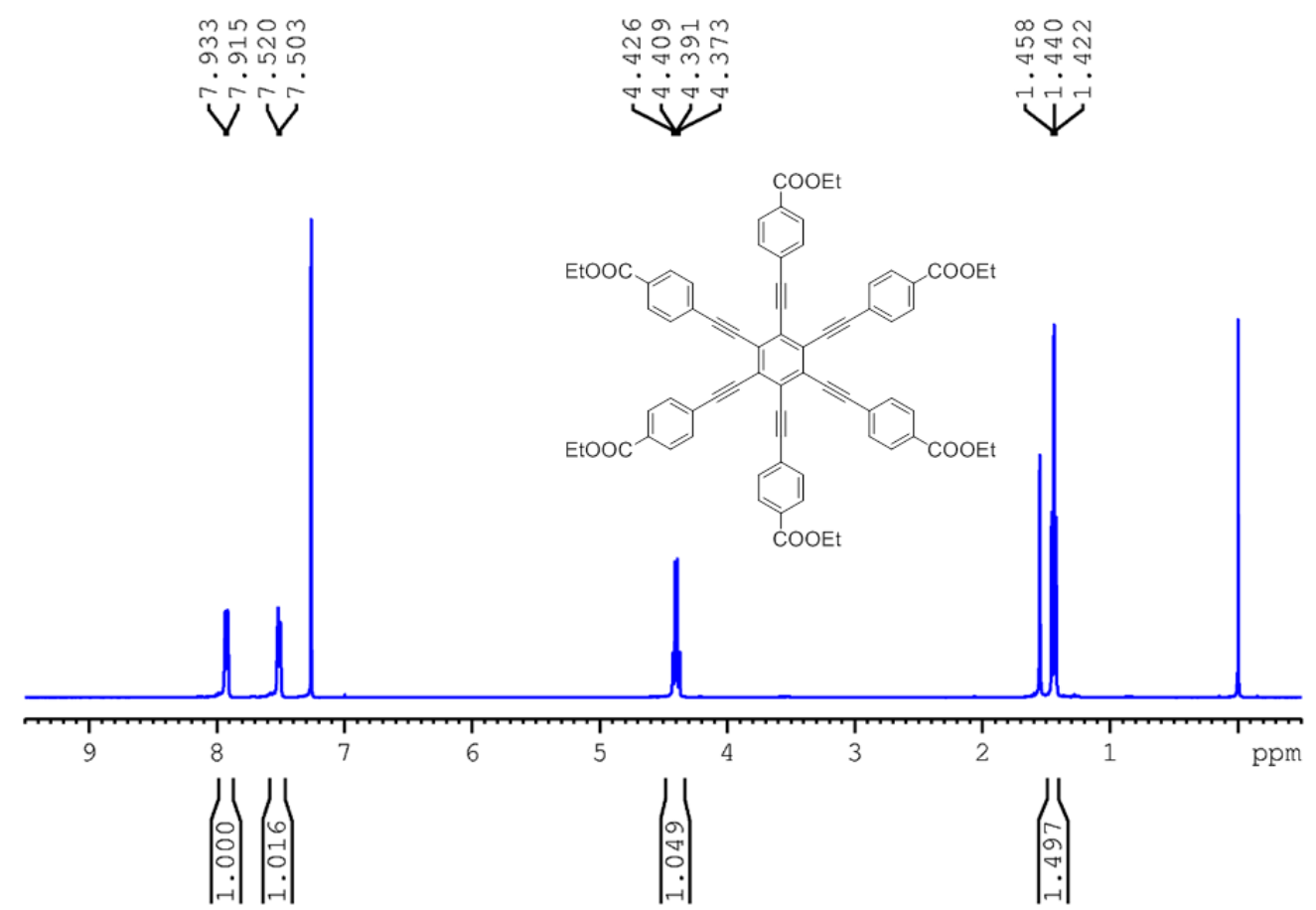

Figure S1. ${ }^{1} \mathrm{H} \mathrm{NMR}\left(\mathrm{CDCl}_{3}, 400 \mathrm{MHz}\right)$ spectrum of compound 1.

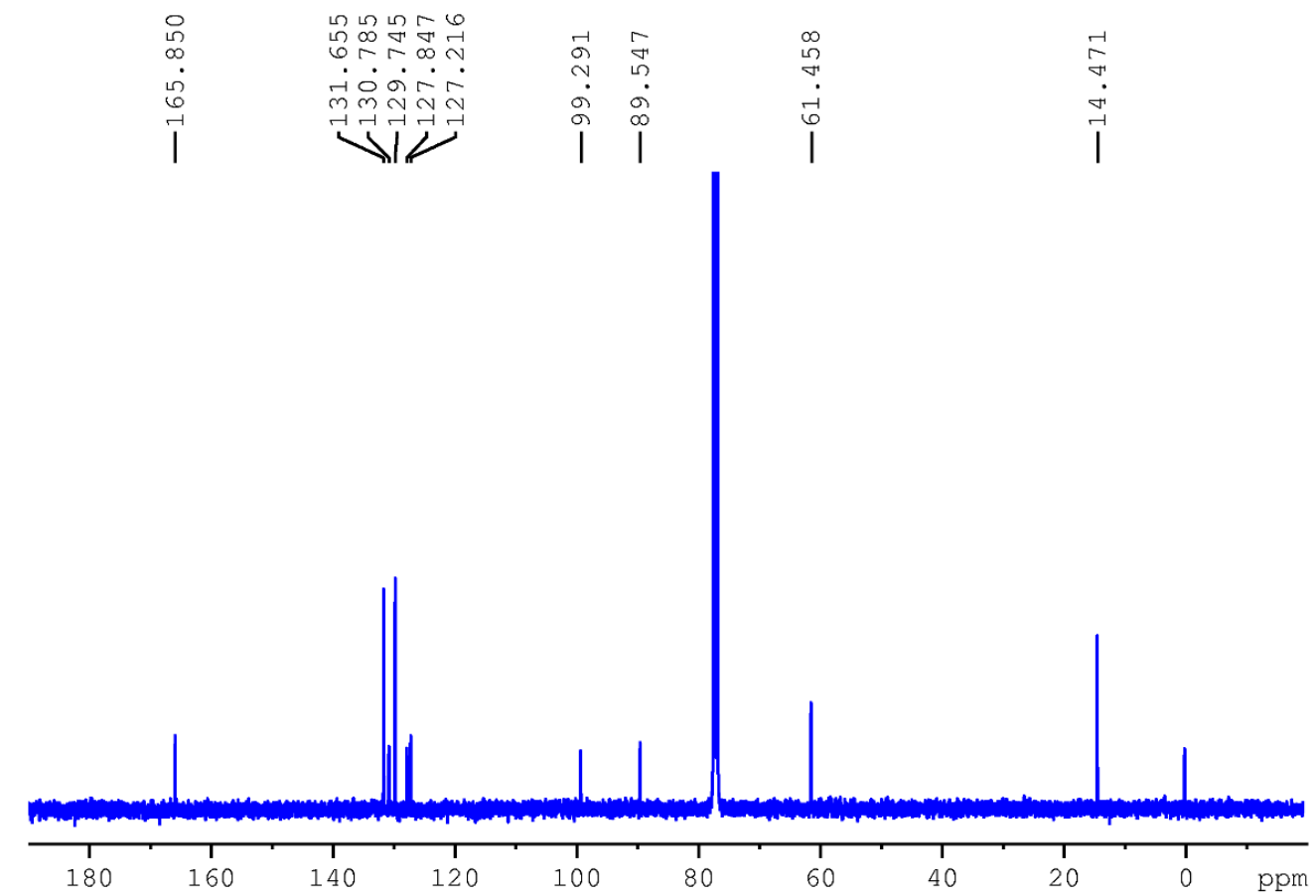

Figure S2. ${ }^{13} \mathrm{C} \mathrm{NMR}\left(\mathrm{CDCl}_{3}, 100 \mathrm{MHz}\right)$ spectrum of compound $\mathbf{1}$. 


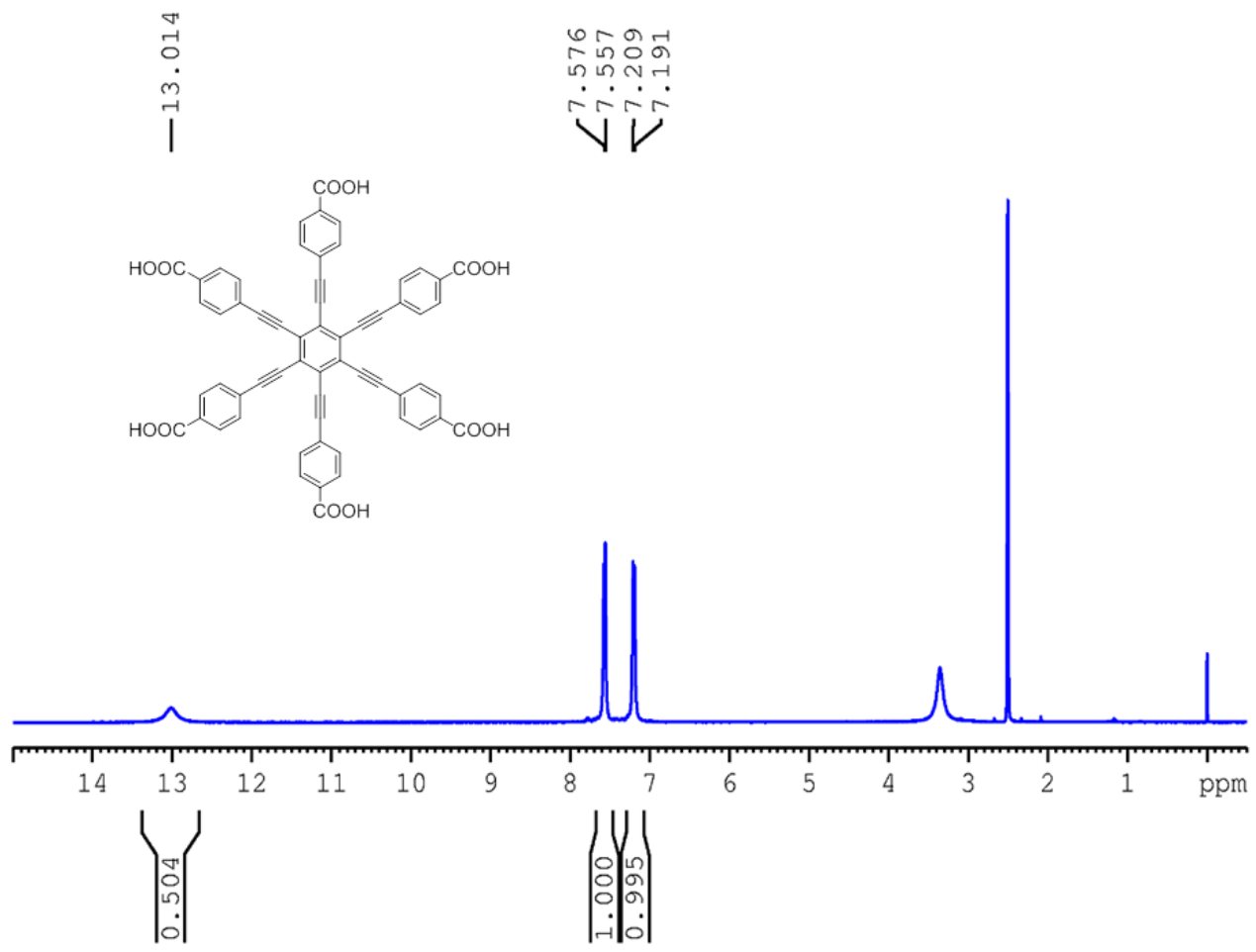

Figure S3. ${ }^{1} \mathrm{H}$ NMR $\left(\mathrm{DMSO}-\mathrm{d}_{6}, 400 \mathrm{MHz}\right)$ spectrum of compound HCEB.

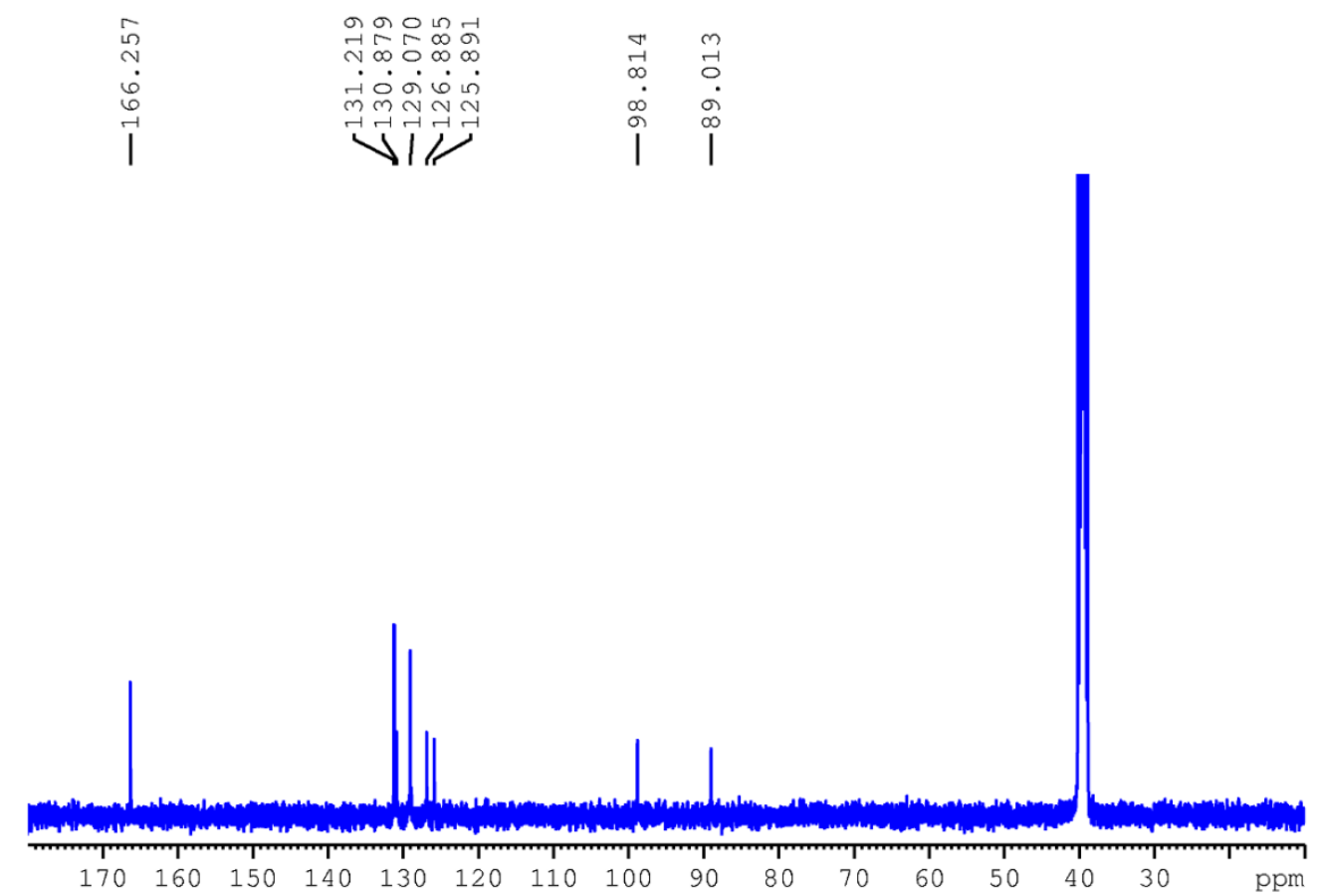

Figure S4. ${ }^{13} \mathrm{C}$ NMR (DMSO- $\mathrm{d}_{6}, 100 \mathrm{MHz}$ ) spectrum of compound HCEB. 

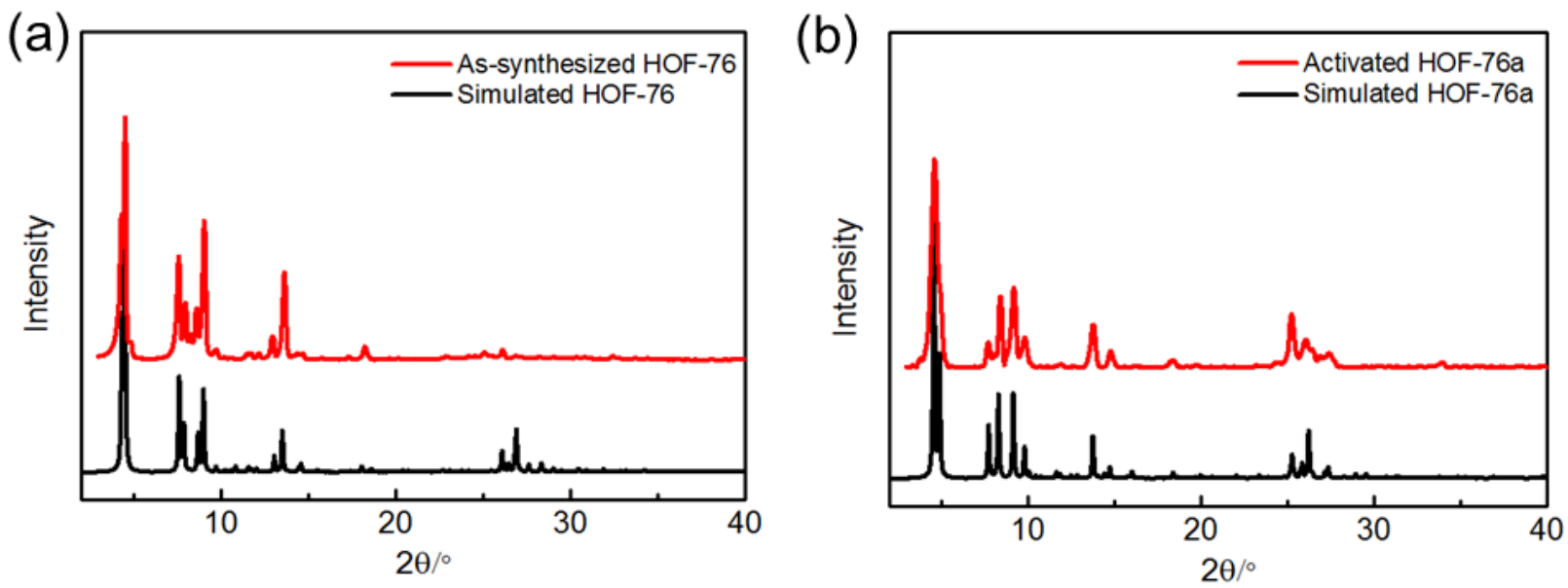

Figure S5. (a) Experimental PXRD pattern of as-synthesized HOF-76 (red) and the calculated pattern based on the single-crystal X-ray structure (black). (b) Experimental PXRD pattern of activated HOF-76a (red) and the calculated pattern based on the HOF-76a structural model (black). The agreement between experiment and simulation is very well. In the HOF-76a structural model, the lattice parameters were obtained from indexing the experimental PXRD pattern of activated HOF-76a. The results show that the HOF-76 crystal structure remains essentially the same upon activation (guest removal), in terms of crystal symmetry and framework arrangement. However, the unit cell parameters do change a bit: As-synthesized HOF-76 (from SXRD data): $a=22.539 ; b=40.639 ; c=13.722$; beta=96.088; Activated HOF-76 (from PXRD data): $a=23.051 ; b=36.025 ; c=14.229$; beta $=98.095$.

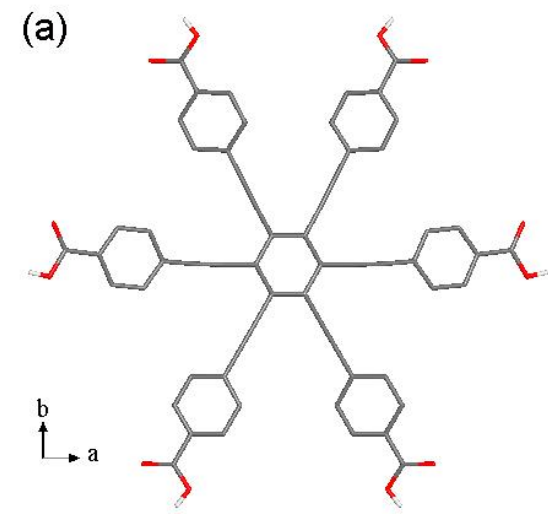

(b)

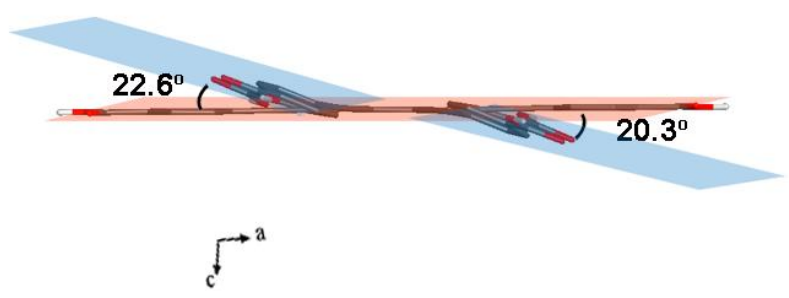

Figure S6. (a) View of the HCEB ligand along $c$-axis; (b) along $b$-axis, indicating that the four outer carboxyphenyl groups alternately direct up and down against the plane of the central benzene ring. 
(a)

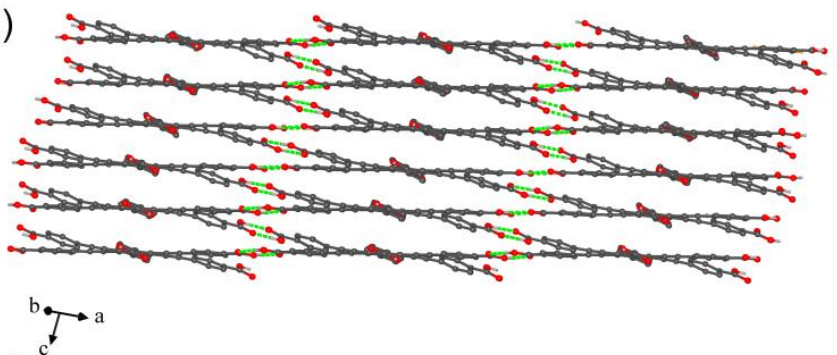

(b)

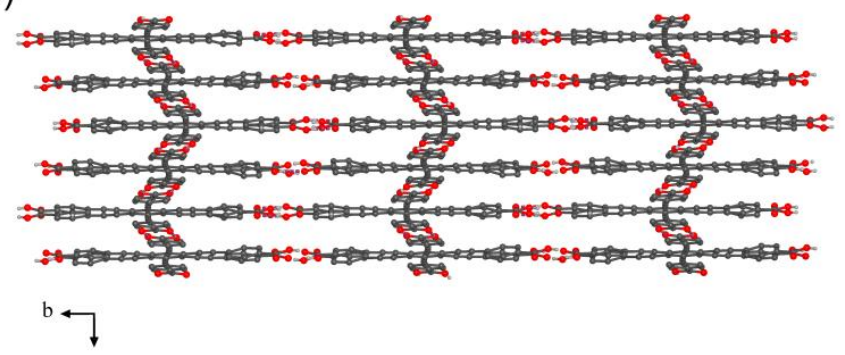

Figure S7. Crystal structure description of HOF-76, showing the hydrogen-bonding connections of the HCEB building blocks to form a three-dimensionally extended H-bonded network viewed two perpendicular directions to channels.

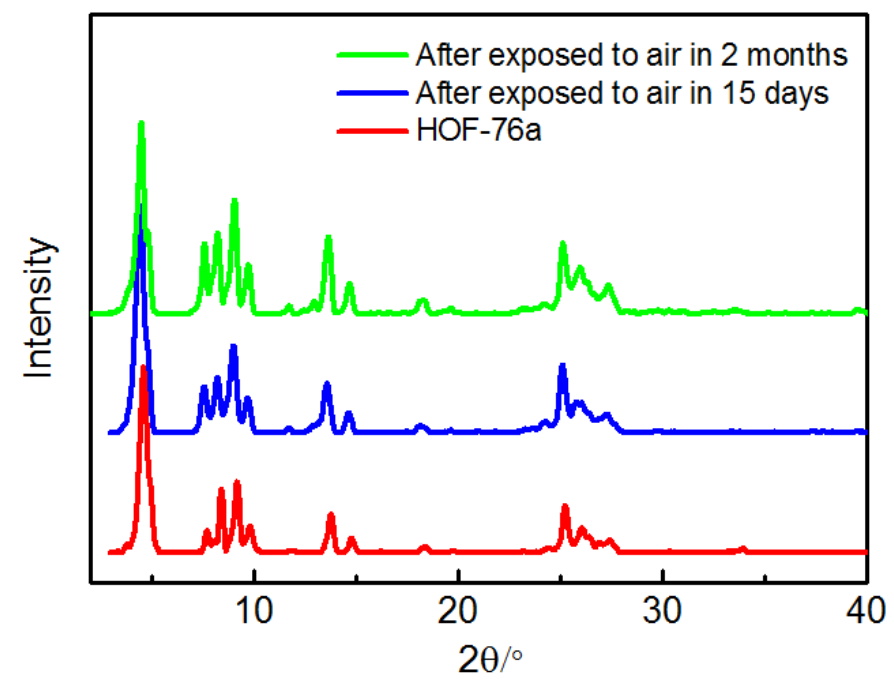

Figure S8. PXRD patterns of activated HOF-76a samples after exposed to air for more than 2 months. 


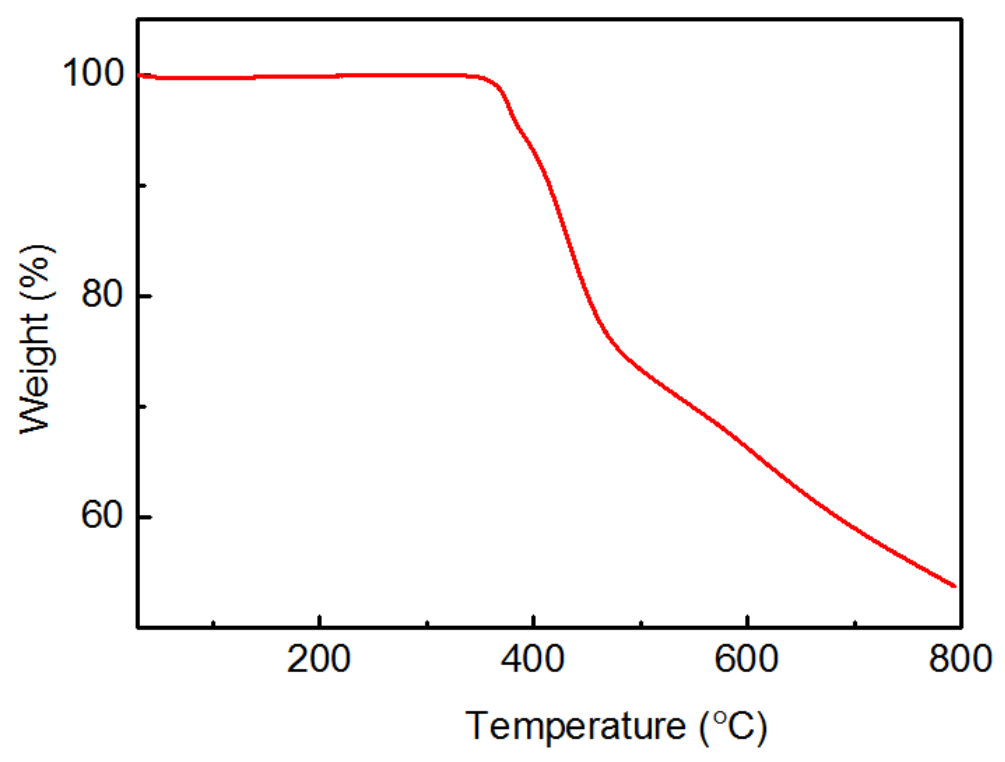

Figure S9. TGA curve of activated HOF-76a.

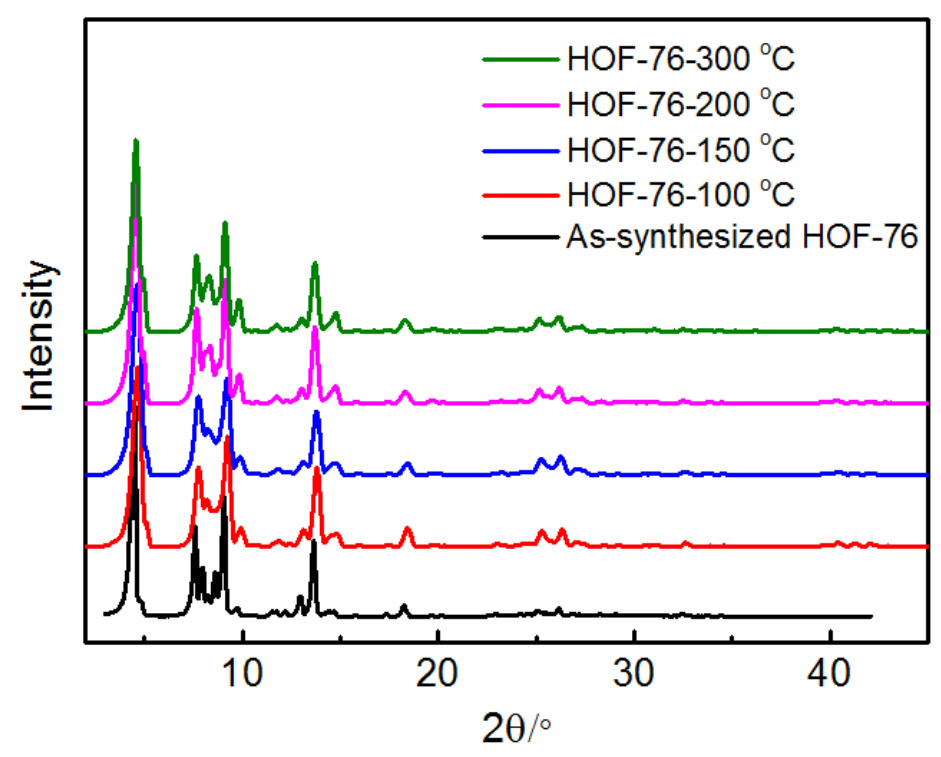

Figure S10. PXRD patterns of HOF-76 sample treated with different temperatures for 2 hours, and compared with the XRD patterns of the as-synthesized sample (black). 

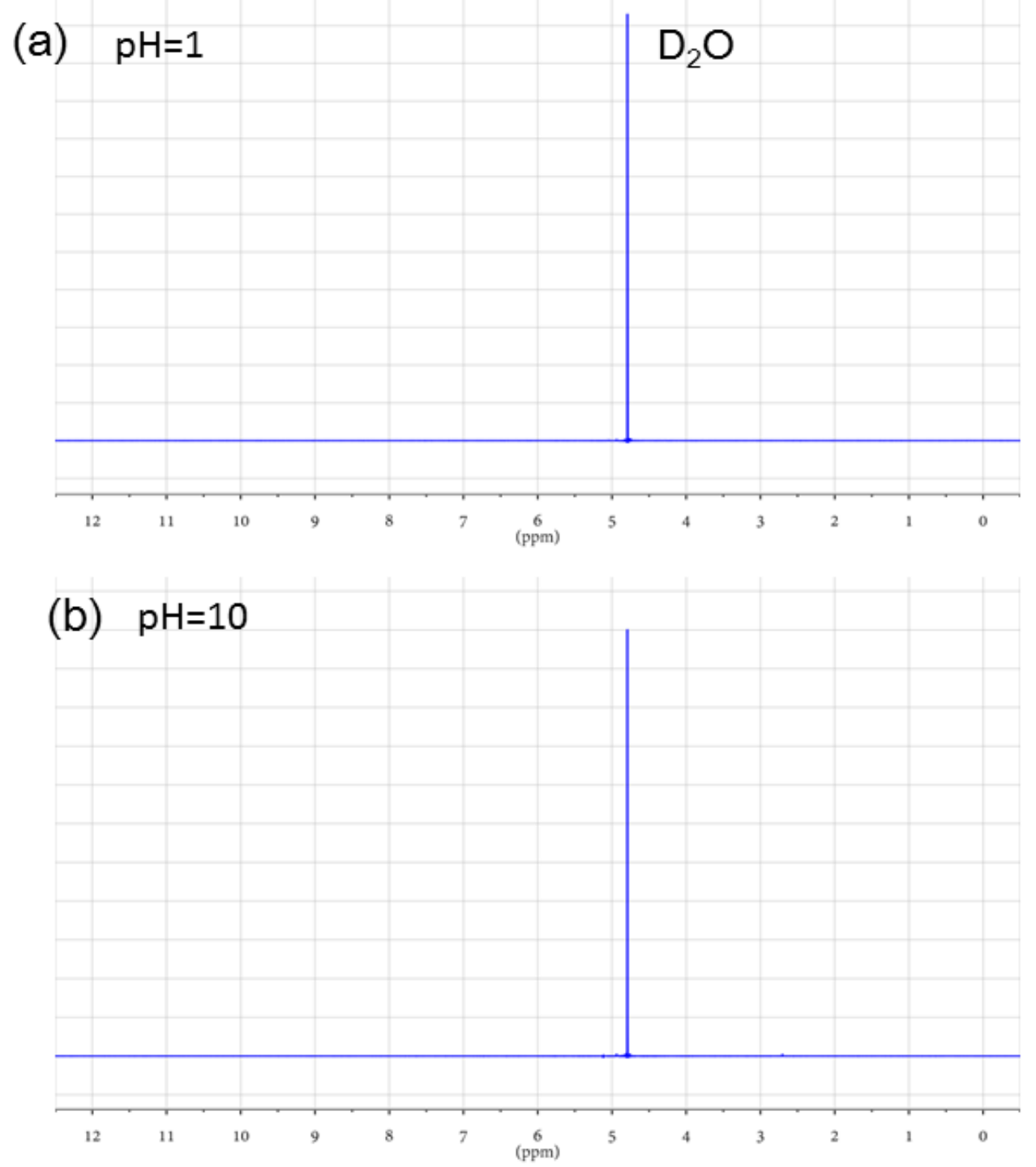

Figure S11. ${ }^{1} \mathrm{H}$ NMR $\left(\mathrm{D}_{2} \mathrm{O}, 400 \mathrm{MHz}\right)$ spectrum of the $\mathrm{D}_{2} \mathrm{O}$ solution after the HOF-76 sample was soaked into (a) the $\mathrm{pH}=1 \mathrm{HCl}$ solution $\left(0.1 \mathrm{~mol} / \mathrm{L} \mathrm{DCl}\right.$ in $\mathrm{D}_{2} \mathrm{O}$ solution) and (b) $\mathrm{pH}=10$ $\mathrm{NaOD}$ solution $\left(0.01 \mathrm{~mol} / \mathrm{L} \mathrm{NaOD}\right.$ in $\mathrm{D}_{2} \mathrm{O}$ solution) for $24 \mathrm{~h}$, and no any ligand signal was detected. 


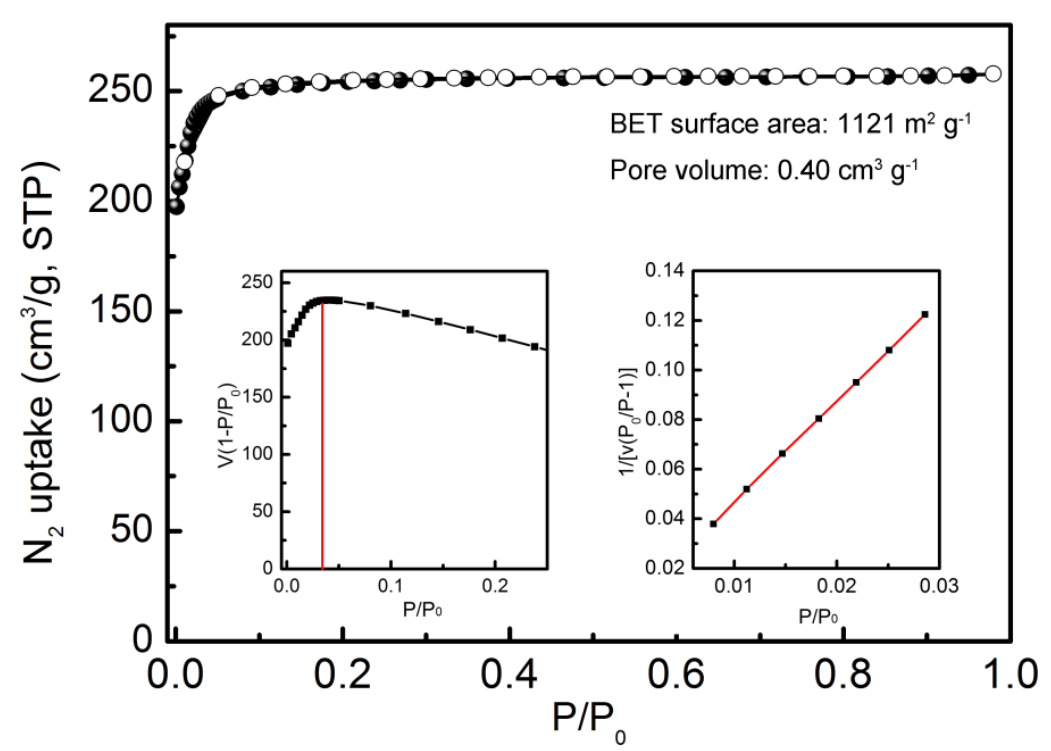

Figure S12. Nitrogen isotherm at $77 \mathrm{~K}$ with consistency and BET plots for the activated HOF76a sample.

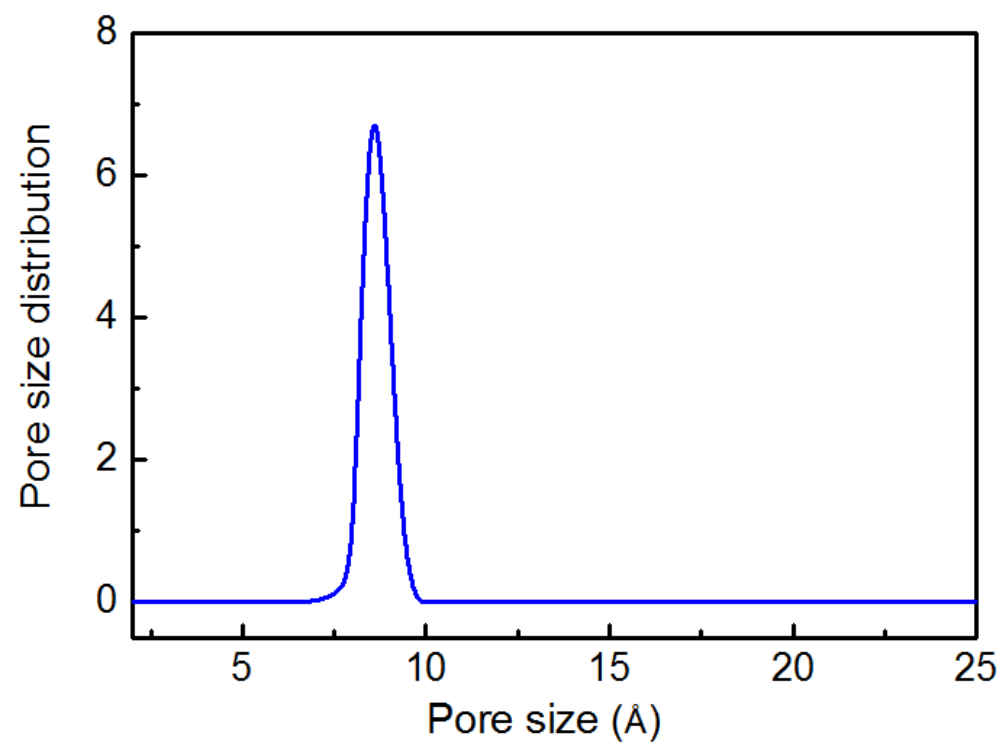

Figure S13. The pore size distribution of HOF-76a determined by $77 \mathrm{~K} \mathrm{~N}_{2}$ isotherms using Non Local Density Functional Theory (NLDFT) method, revealing a calculated pore size of $8.5 \AA$. 


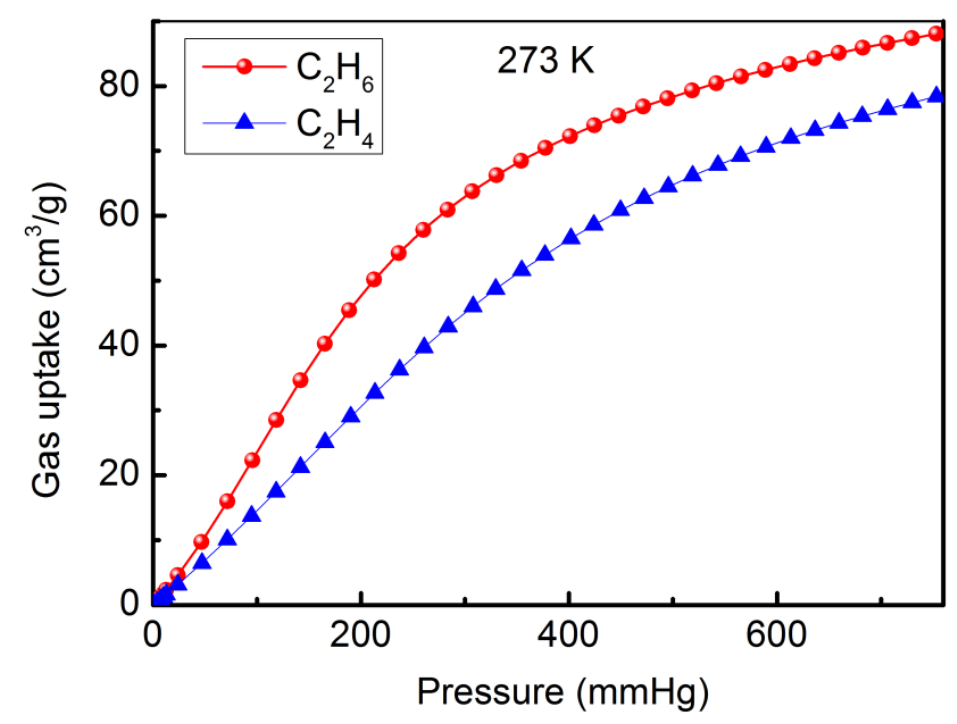

Figure S14. Adsorption isotherms of $\mathrm{C}_{2} \mathrm{H}_{6}$ (red) and $\mathrm{C}_{2} \mathrm{H}_{4}$ (blue) for HOF-76a at $273 \mathrm{~K}$ up to 1 bar.

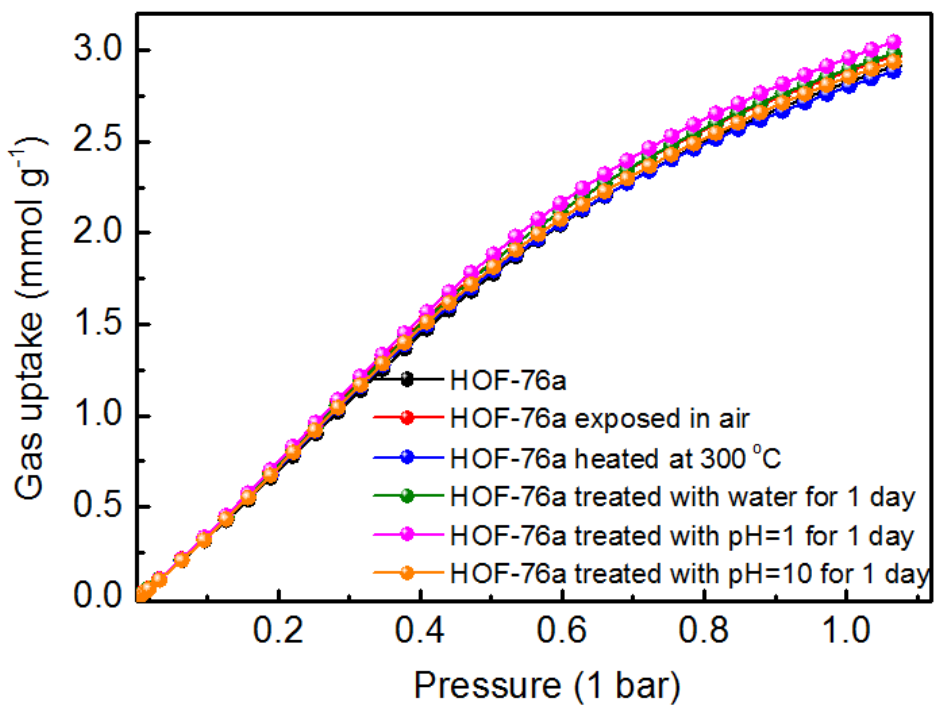

Figure S15. Gas sorption isotherms of $\mathrm{C}_{2} \mathrm{H}_{6}$ at $296 \mathrm{~K}$ for HOF-76a (black), re-activated HOF76 a after exposure to air for 15 days (red), heated at $300{ }^{\circ} \mathrm{C}$ for $2 \mathrm{~h}$, and treated with water-, acidand base-treated HOF-76a. 


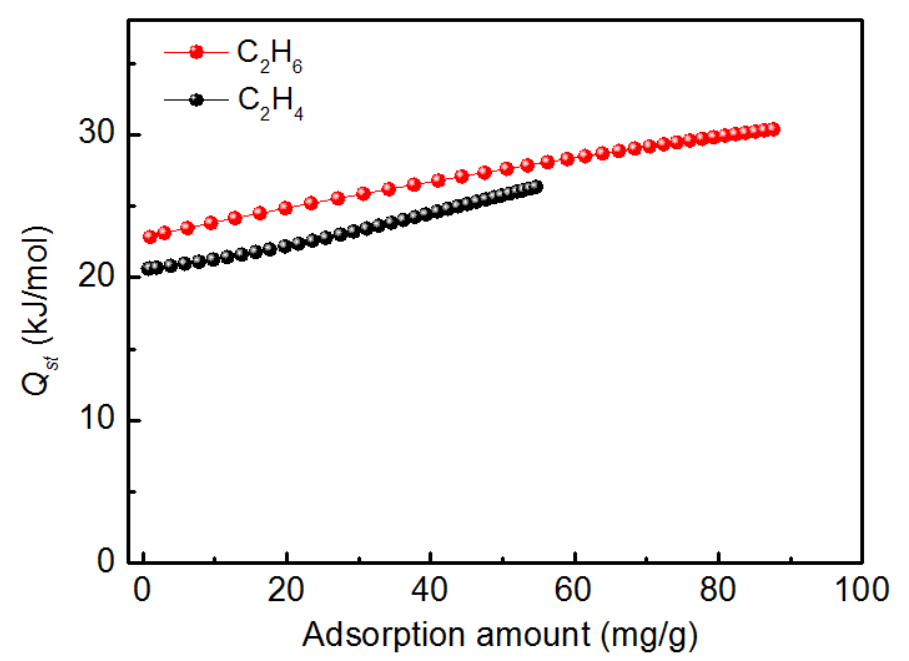

Figure S16. Adsorption heat of the $\mathrm{C}_{2} \mathrm{H}_{6}$ (red) and $\mathrm{C}_{2} \mathrm{H}_{4}$ (black) for HOF-76a.
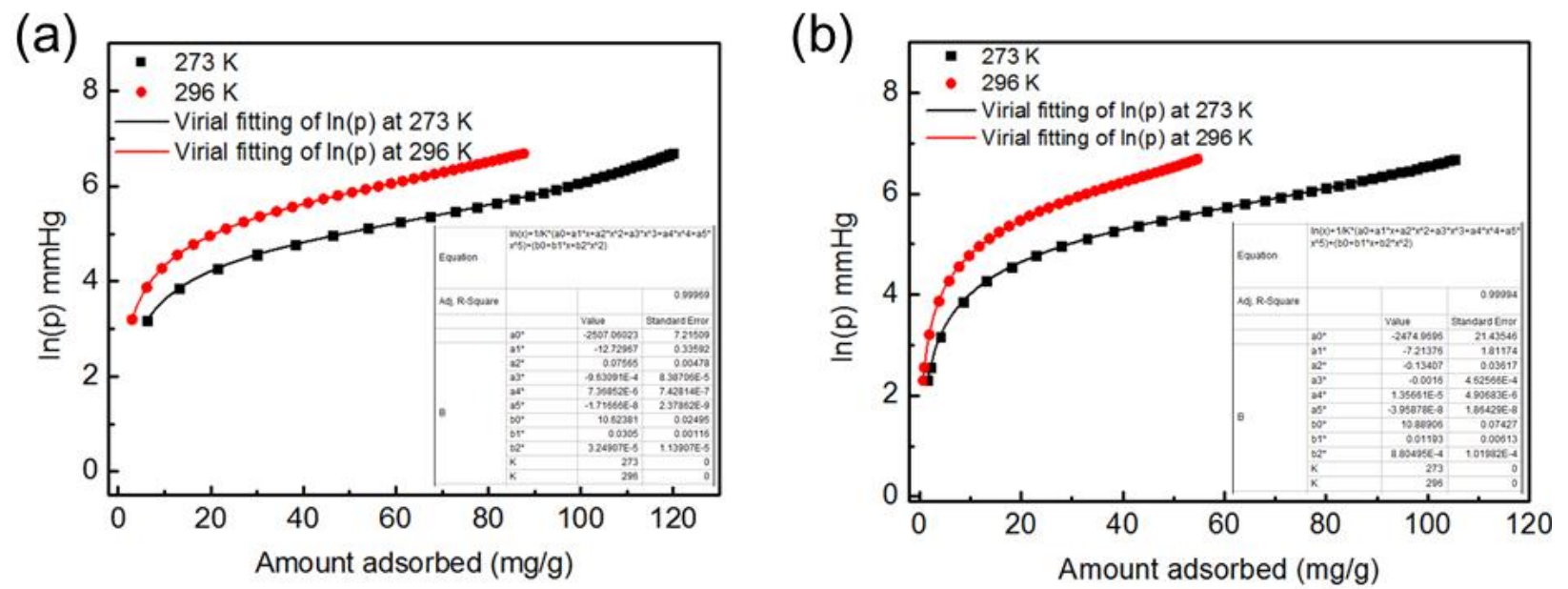

Figure S17. Virial fitting of the $\mathrm{C}_{2} \mathrm{H}_{6}$ (a) and $\mathrm{C}_{2} \mathrm{H}_{4}$ (b) adsorption isotherms for HOF-76a. 


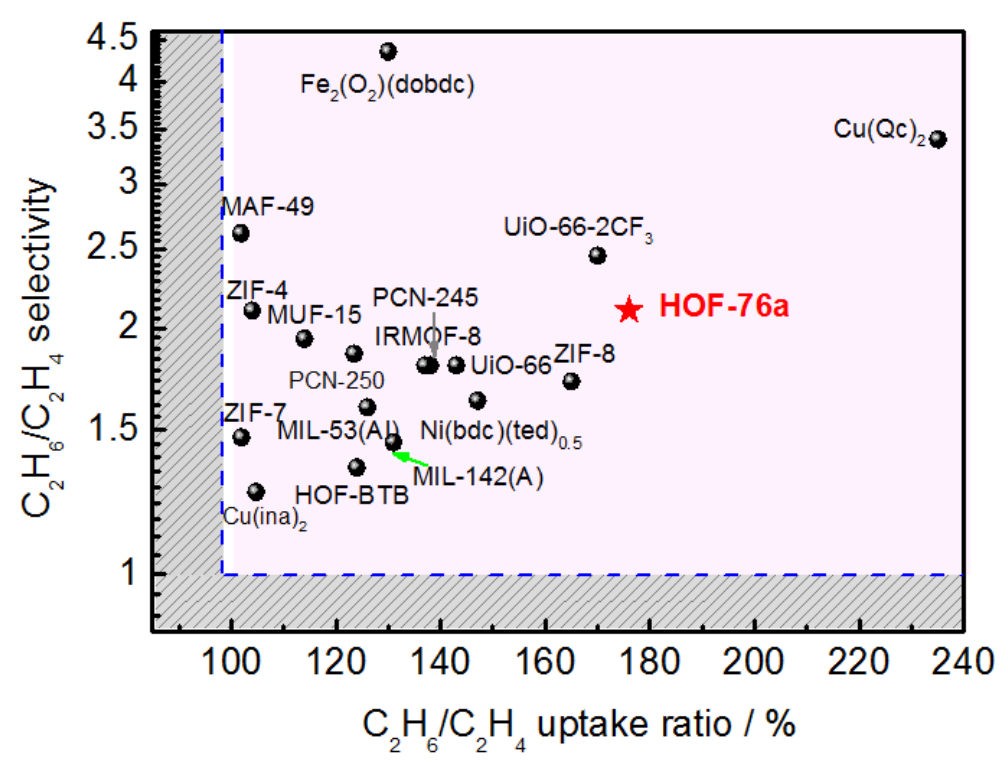

Figure S18. $\mathrm{C}_{2} \mathrm{H}_{6} / \mathrm{C}_{2} \mathrm{H}_{4}$ IAST selectivity/uptake ratio for HOF-76a (2.05 and 177\%) verses the indicated $\mathrm{C}_{2} \mathrm{H}_{6}$-selective MOF materials at 1 bar and room temperature, indicating that HOF-76a is superior to most of MOFs and the only HOF reported (HOF-BTB: 1.4 and 124\%) ${ }^{23}$. HOF-76a is evidently placed among the best-performing materials reported for $\mathrm{C}_{2} \mathrm{H}_{6} / \mathrm{C}_{2} \mathrm{H}_{4}$ separation.

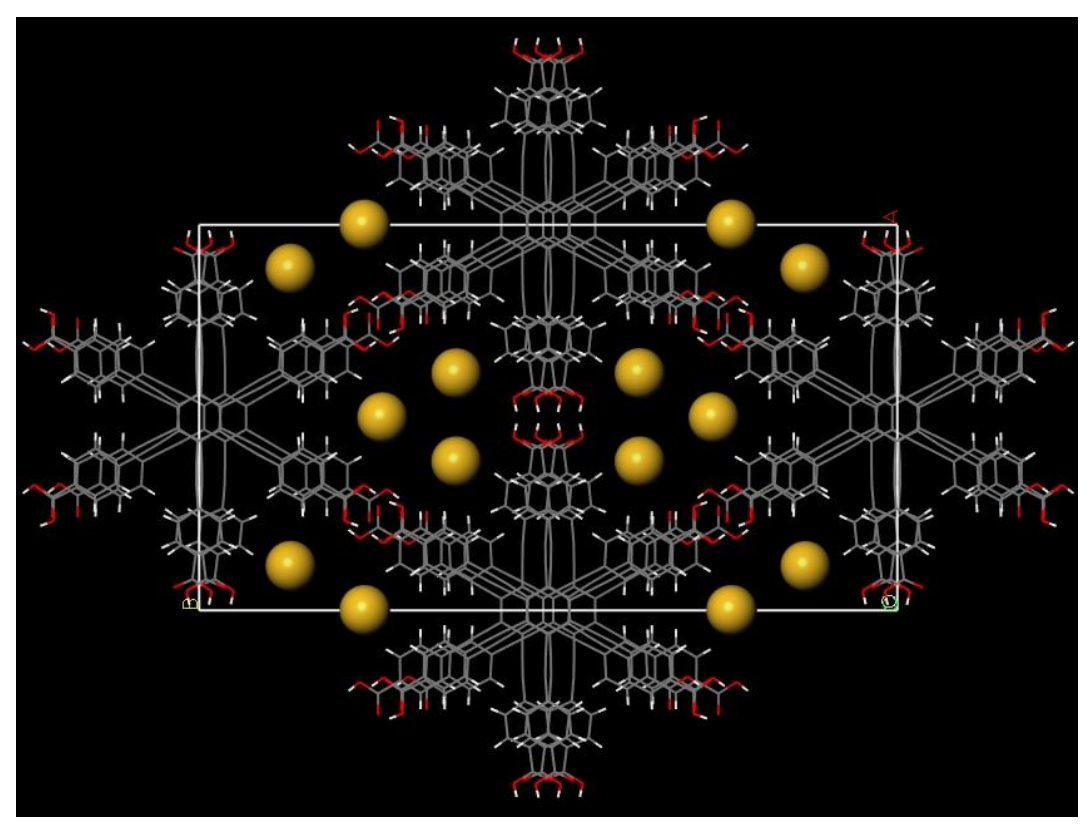

Figure S19. A local structure of HOF-76a showing all the corner sites (yellow ball) for gas adsorption, and there exist 24 such "corner sites" within each unit cell. 

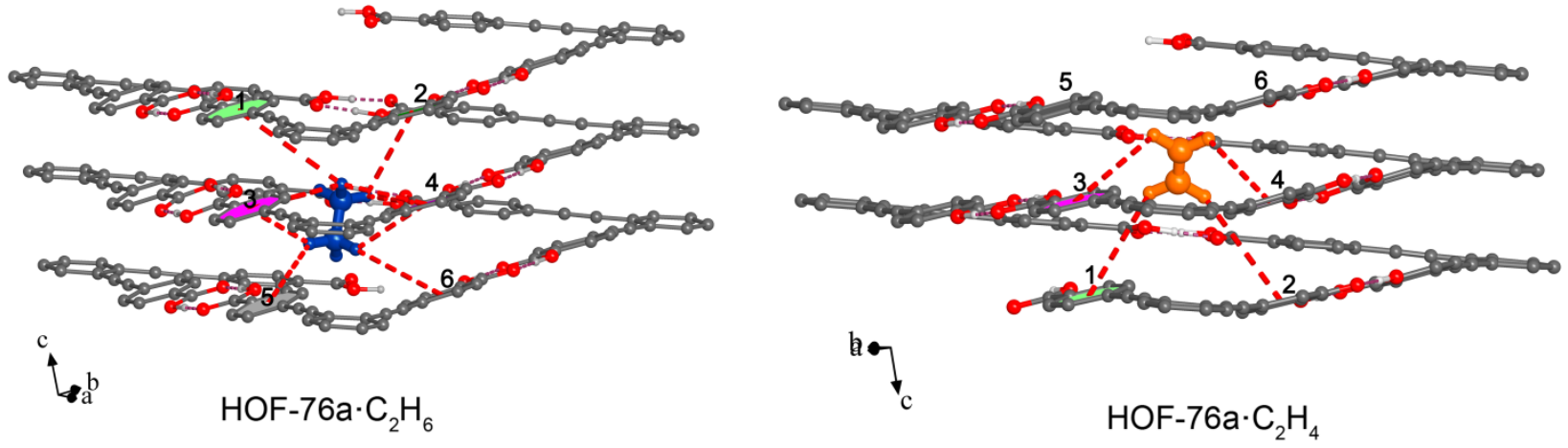

Figure S20. Comparison of the preferential $\mathrm{C}_{2} \mathrm{H}_{4}$ and $\mathrm{C}_{2} \mathrm{H}_{6}$ adsorption sites and the close vdW contacts within the corner surface of triangular channel- like pores observed by DFT calculations (C, dark gray; $\mathrm{O}$, red; $\mathrm{H}$, white), highlighting the $\mathrm{C}-\mathrm{H}^{\cdots} \pi$ interactions in red dashed bonds.

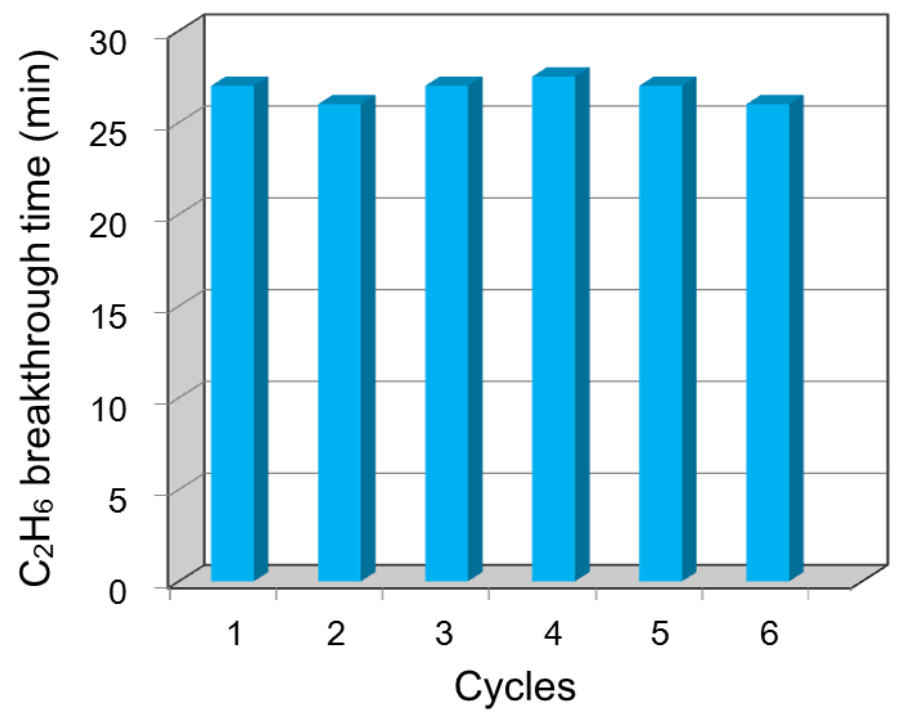

Figure S21. Cyclic breakthrough experiments for $\mathrm{C}_{2} \mathrm{H}_{6} / \mathrm{C}_{2} \mathrm{H}_{4}$ (50/50) separation on HOF-76a, indicating that HOF-76a maintained the $\mathrm{C}_{2} \mathrm{H}_{6}$ breakthrough time during the separation processes over at least 6 times. 


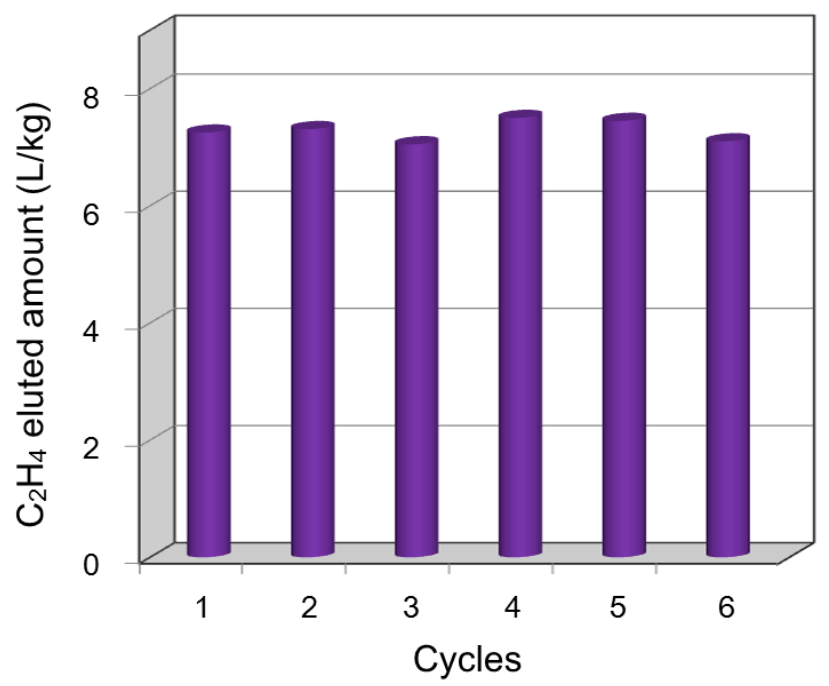

Figure S22. Cyclic breakthrough experiments for $\mathrm{C}_{2} \mathrm{H}_{6} / \mathrm{C}_{2} \mathrm{H}_{4}(50 / 50)$ separation on HOF-76a, indicating that HOF-76a maintained the $\mathrm{C}_{2} \mathrm{H}_{4}$ eluted amount during the separation processes over at least 6 times.

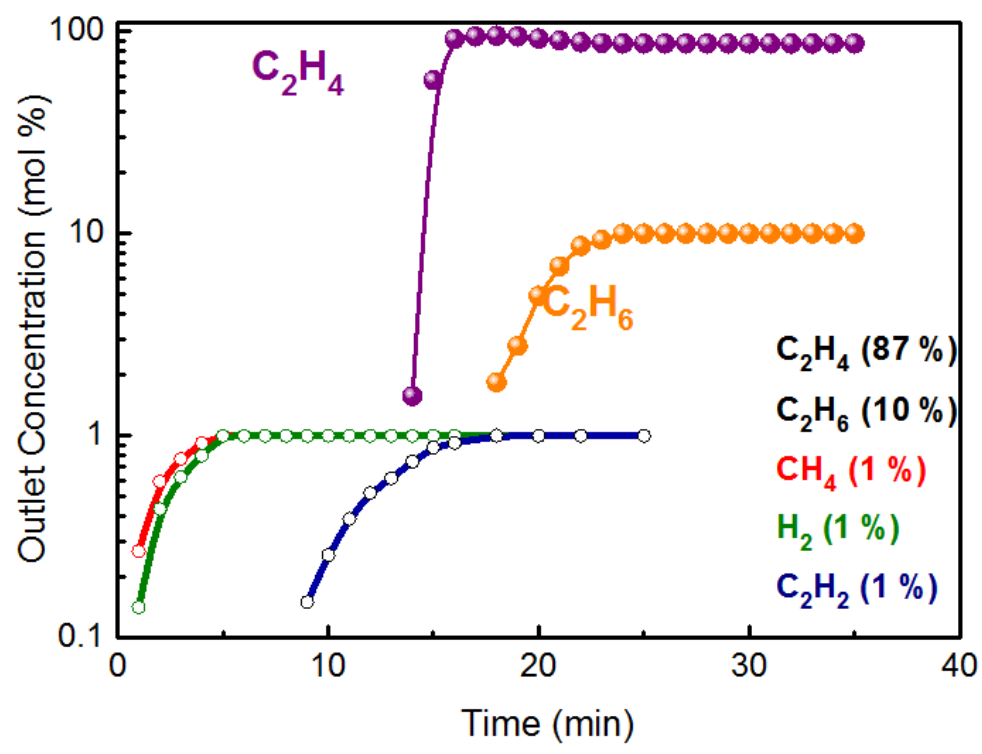

Figure S23. Experimental column breakthrough curves for a $\mathrm{C}_{2} \mathrm{H}_{6} / \mathrm{C}_{2} \mathrm{H}_{4} / \mathrm{C}_{2} \mathrm{H}_{2} / \mathrm{CH}_{4} / \mathrm{H}_{2}$ $(10 / 87 / 1 / 1 / 1)$ mixture under a total flow of $1.25 \mathrm{~mL} \mathrm{~min}^{-1}$ in an absorber bed packed with HOF$76 \mathrm{a}$ at $298 \mathrm{~K}$ and 1.01 bar. 


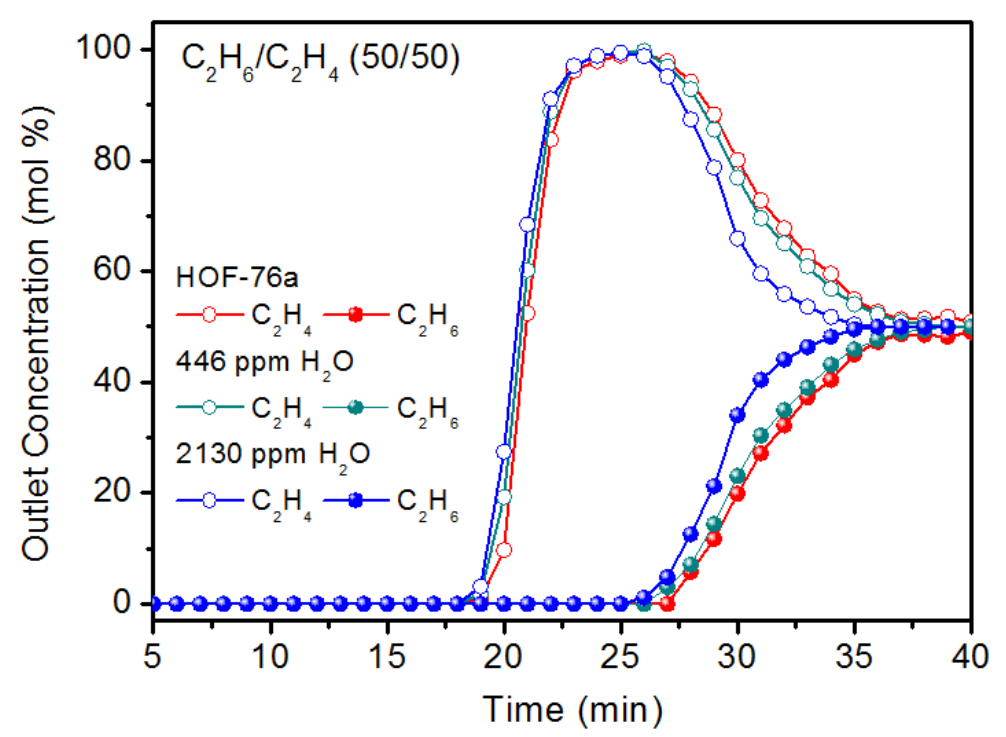

Figure S24. Experimental column breakthrough curves for $\mathrm{C}_{2} \mathrm{H}_{6} / \mathrm{C}_{2} \mathrm{H}_{4}$ separations (50/50, v/v) on HOF-76a at $298 \mathrm{~K}$ and 1.01 bar with different amounts of $\mathrm{H}_{2} \mathrm{O}$, indicating that small amounts of water have a negligible effect on the separation performance.
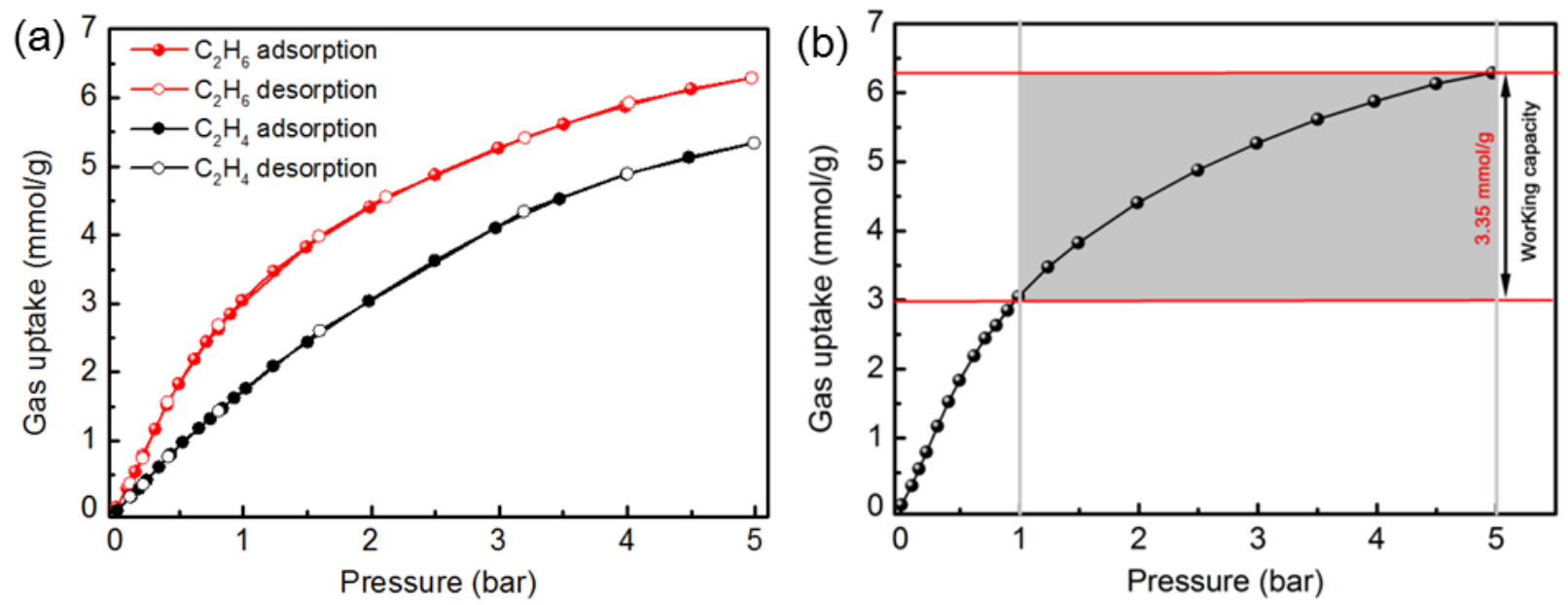

Figure S25. (a) Adsorption isotherms of $\mathrm{C}_{2} \mathrm{H}_{6}$ (red) and $\mathrm{C}_{2} \mathrm{H}_{4}$ (black) for $\mathrm{HOF}-76 \mathrm{a}$ at $298 \mathrm{~K}$ up to 5 bar. (b) Schematic diagram of the determination of the working capacity of HOF-76a at RT, as required by pressure-swing adsorption (PSA) processes. Here the working capacity is defined as the different amounts adsorbed between 1 and 5 bar, if a PSA regeneration step is considered at near-ambient pressure $(\approx 100 \mathrm{kPa}){ }^{14}$ 


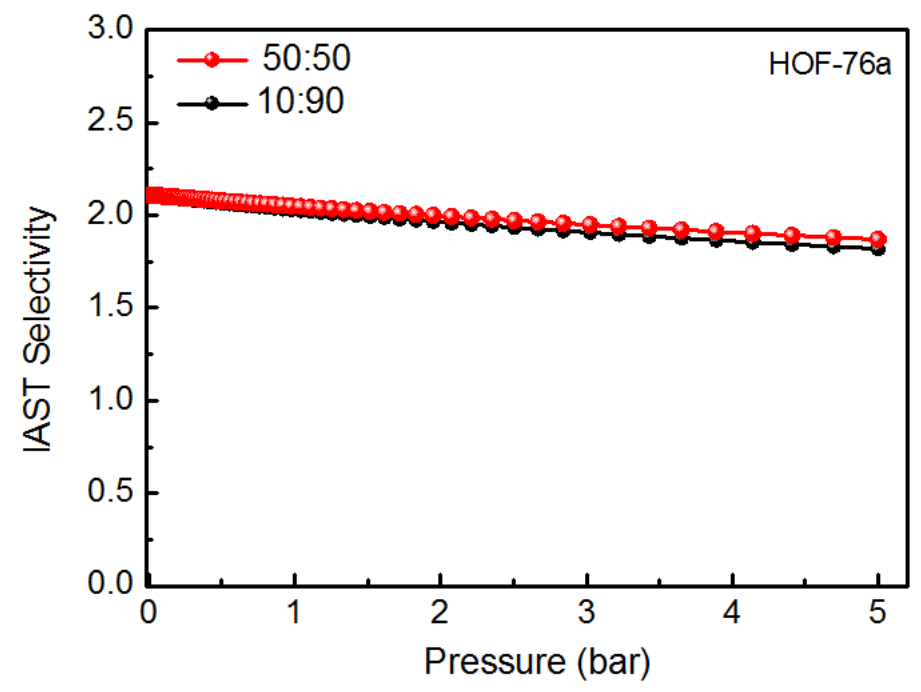

Figure S26. IAST selectivity of HOF-76a from $\mathrm{C}_{2} \mathrm{H}_{6} / \mathrm{C}_{2} \mathrm{H}_{4}$ (50/50 and 10/90) gas mixtures up to 5 bar, calculated on $\mathrm{C}_{2} \mathrm{H}_{6}$ and $\mathrm{C}_{2} \mathrm{H}_{4}$ high-pressure adsorption isotherms at $298 \mathrm{~K}$.
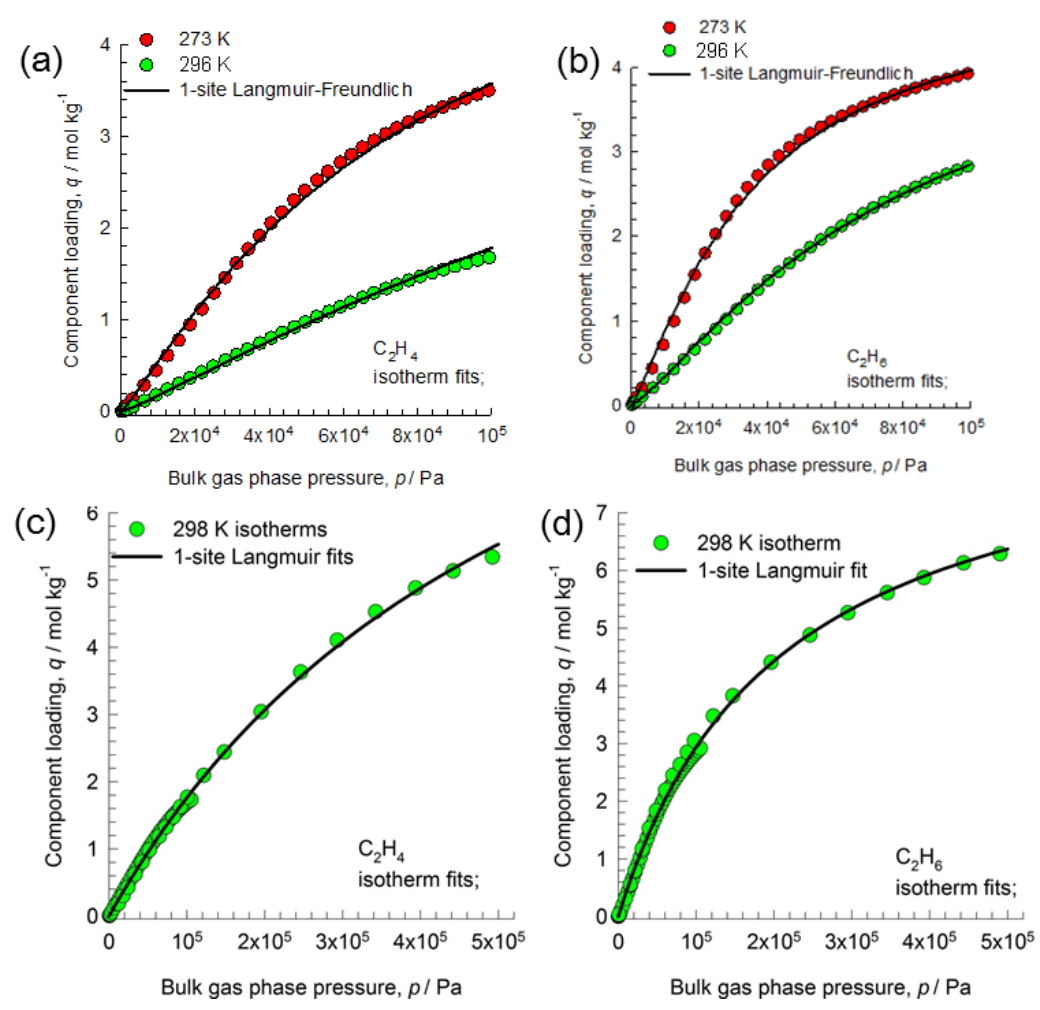

Figure S27. (a) Comparison of component loadings for $\mathrm{C}_{2} \mathrm{H}_{4}$ and (b) $\mathrm{C}_{2} \mathrm{H}_{6}$ at 1 bar in $\mathrm{HOF}-76 \mathrm{a}$ with the 1-site Langmuir-Freundlich isotherm fits; (c) for $\mathrm{C}_{2} \mathrm{H}_{4}$ and (d) $\mathrm{C}_{2} \mathrm{H}_{6}$ at 5 bar and $298 \mathrm{~K}$. 


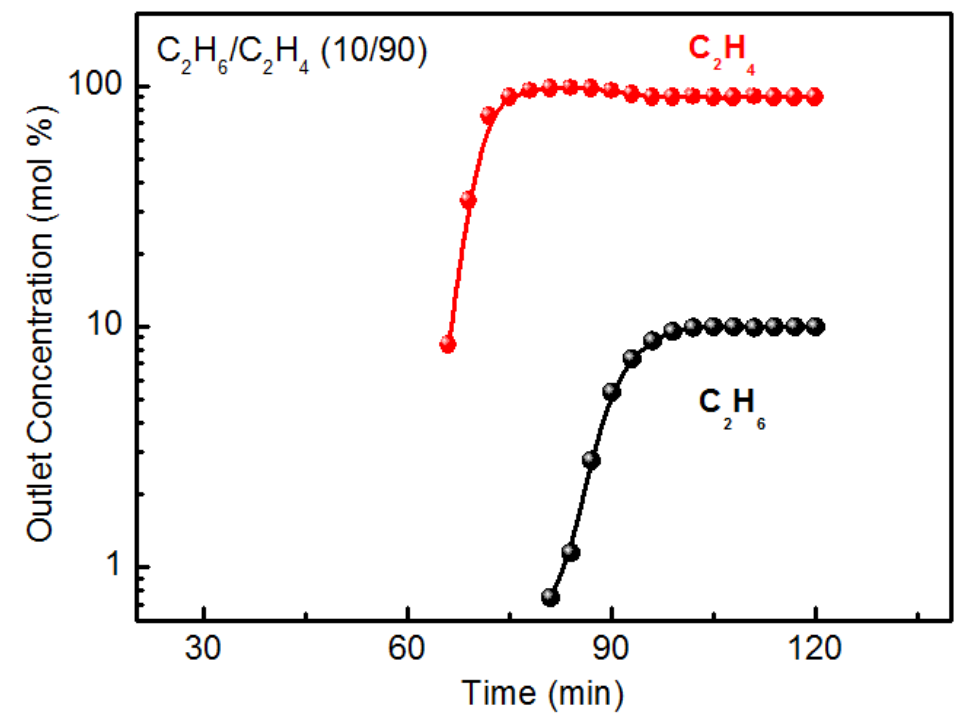

Figure S28. Experimental column breakthrough curves for a $\mathrm{C}_{2} \mathrm{H}_{6} / \mathrm{C}_{2} \mathrm{H}_{4}(10 / 90)$ mixture in an absorber bed packed with HOF-76a at $298 \mathrm{~K}$ and 5.0 bar.

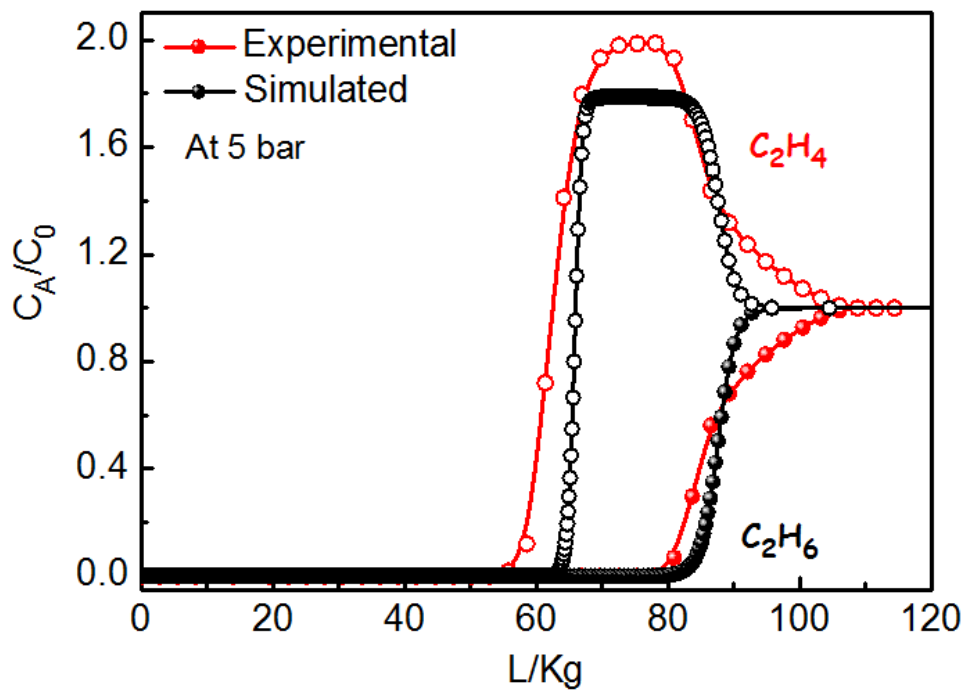

Figure S29. Comparison of the experimental and simulated breakthrough curves for $\mathrm{C}_{2} \mathrm{H}_{6} / \mathrm{C}_{2} \mathrm{H}_{4}$ separation $(50 / 50, \mathrm{v} / \mathrm{v})$ on HOF-76a under the same separation parameters at $298 \mathrm{~K}$ and 5.0 bar, indicating that the simulations are in good agreement with the experimental results. The $\mathrm{X}$-axis represents $\frac{(\text { time in minutes }) \times(\text { flow rate } \mathrm{mL} / \mathrm{min} \mathrm{STP})}{(\mathrm{g} \text { MOF packed in tube })}=\mathrm{mL} / \mathrm{g}$. 


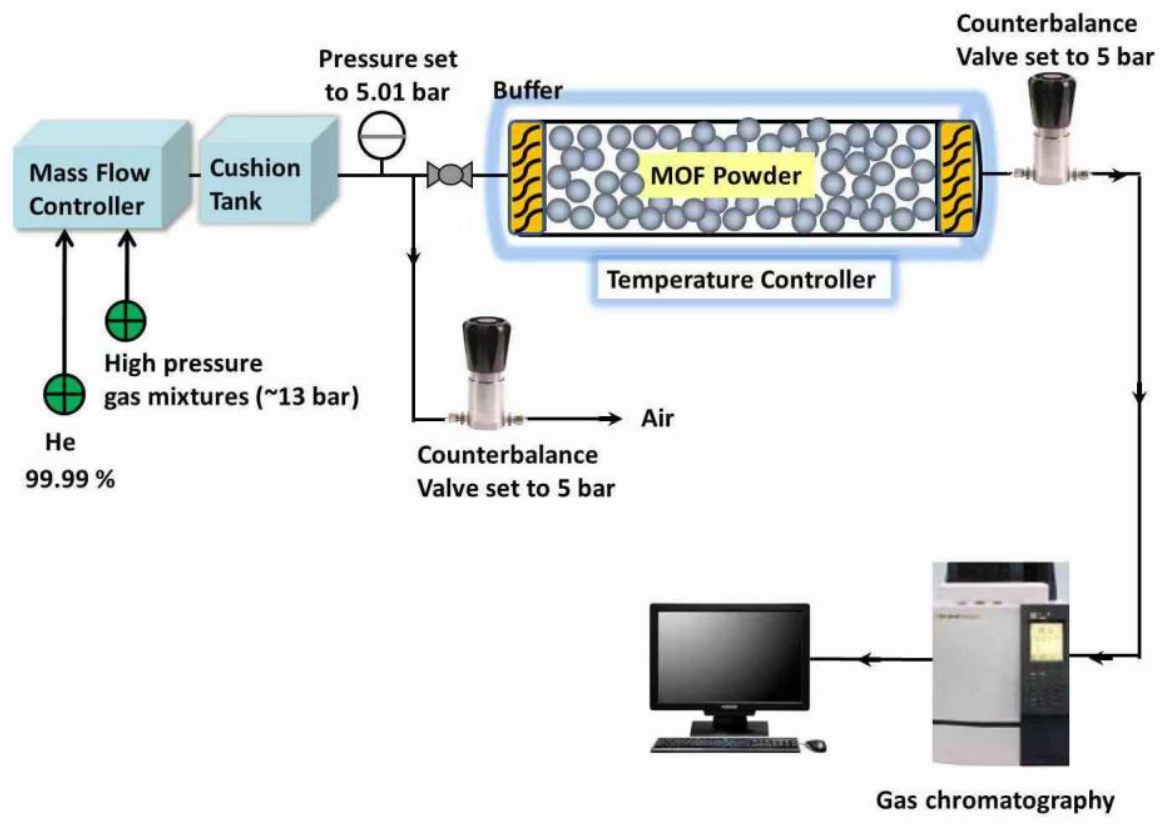

Figure S30. Schematic illustration of the apparatus for the high-pressure breakthrough experiments.

\section{REFERENCES}

[1] Krishna, R. Screening Metal-Organic Frameworks for Mixture Separations in Fixed-Bed Adsorbers using a Combined Selectivity/Capacity Metric. RSC Adv. 2017, 7, 35724-35737.

[2] Krishna, R. Methodologies for Screening and Selection of Crystalline Microporous Materials in Mixture Separations. Sep. Purif. Technol. 2018, 194, 281-300.

[3] Hu, F.; Liu, C.; Wu, M.; Pang, J.; Jiang, F.; Yuan, D.; Hong, M. An Ultrastable and Easily Regenerated Hydrogen-Bonded Organic Molecular Framework with Permanent Porosity. Angew. Chem. Int. Ed. 2017, 56, 2101-2104.

[4] Yin, Q.; Zhao, P.; Sa, R.-J.; Chen, G.-C.; Lg, J.; Liu, T.-F.; Cao, R. An Ultra-Robust and Crystalline Redeemable Hydrogen-Bonded Organic Framework for Synergistic ChemoPhotodynamic Therapy. Angew. Chem. Int. Ed. 2018, 57, 7691-7696.

[5] Hisaki, I.; Nakagawa, S.; Ikenaka, N.; Imamura, Y.; Katouda, M.; Tashiro, M.; Tsuchida, H.; Ogoshi, T.; Sato, H.; Tohnai, N.; Miyata, M. A Series of Layered Assemblies of Hydrogen- 
Bonded, Hexagonal Networks of $\mathrm{C}_{3}$-Symmetric $\pi$-Conjugated Molecules: A Potential Motif of Porous Organic Materials. J. Am. Chem. Soc. 2016, 138, 6617-6628.

[6] Li, P.; Li, P.; Ryder, M. R.; Liu, Z.; Stern, C. L.; Farha, O. K.; Stoddart, J. F. Interpenetration Isomerism in Triptycene-Based Hydrogen-Bonded Organic Frameworks. Angew. Chem. Int. Ed. 2019, 58, 1664-1669.

[7] Yoon, T.-U.; Baek, S. B.; Kim, D.; Kim, E.-J.; Lee, W.-G.; Singh, B. K.; Lah, M. S.; Bae, Y.S.; Kim, K. S. Efficient separation of $\mathrm{C}_{2}$ hydrocarbons in a permanently porous hydrogenbonded organic framework. Chem. Commun. 2018, 54, 9360-9363.

[8] Nandi, S.; Chakraborty, D.; Vaidhyanathan, R. A permanently porous single molecule Hbonded organic framework for selective $\mathrm{CO}_{2}$ capture. Chem. Commun. 2016, 52, 7249-7252.

[9] Bassanetti, I.; Bracco, S.; Comotti, A.; Negroni, M.; Bezuidenhout, C.; Canossa, S.; Mazzeo, P. P.; Marchió, L.; Sozzani, P. Flexible porous molecular materials responsive to $\mathrm{CO}_{2}, \mathrm{CH}_{4}$ and Xe stimuli. J. Mater. Chem. A 2018, 6, 14231-14239.

[10] Li, L.; Lin, R.-B.; Krishna, R.; Li, H.; Xiang, S.; Wu, H.; Li, J.; Zhou, W.; Chen, B. Ethane/ethylene separation in a metal-organic framework with iron-peroxo sites. Science 2018, $362,443-446$.

[11] Qazvini, O. T.; Babarao, R.; Shi, Z.-L.; Zhang, Y.-B.; Telfer, S. G. A Robust EthaneTrapping Metal-Organic Framework with a High Capacity for Ethylene Purification. J. Am. Chem. Soc. 2019, 141, 5014-5020.

[12] Liao, P. Q.; Zhang, W. X.; Zhang, J. P.; Chen, X. M. Efficient purification of ethene by an ethane-trapping metal-organic framework. Nat. Commun. 2015, 6, 8697.

[13] Lin, R.-B.; Wu, H.; Li, L.; Tang, X.-L.; Li, Z.; Gao, J.; Cui, H.; Zhou, W.; Chen, B. Boosting ethane/ethylene separation within isoreticular ultramicroporous metal-organic frameworks. J. Am. Chem. Soc. 2018, 140, 12940-12946.

[14] Pires, J.; Fernandes, J.; Dedecker, K.; Gomes, J. R. B.; Pérez-Sánchez, G.; Nouar, F.; Serre, C.; Pinto, M. L. Enhancement of ethane selectivity in ethane-ethylene mixtures by perfluoro 
groups in Zr-based metal-organic frameworks. ACS Appl. Mater. Interfaces 2019, 11, 2741027421.

[15] Chen, Y.; Qiao, Z.; Wu, H.; Lv, D.; Shi, R.; Xia, Q.; Zhou, J.; Li, Z. An ethane-trapping MOF PCN-250 for highly selective adsorption of ethane over ethylene. Chem. Eng. Sci. 2018, $175,110-117$.

[16] Lv, D.; Shi, R.; Chen, Y.; Wu, Y.; Wu, H.; Xi, H.; Xia, Q.; Li, Z. Selective Adsorption of Ethane over Ethylene in PCN-245: Impacts of Interpenetrated Adsorbent. ACS Appl. Mater. Interfaces 2018, 10, 8366-8373.

[17] Liang, W.; Xu, F.; Zhou, X.; Xiao, J.; Xia, Q.; Li, Y.; Li, Z. Ethane selective adsorbent $\mathrm{Ni}(\mathrm{bdc})(\text { ted })_{0.5}$ with high uptake and its significance in adsorption separation of ethane and ethylene. Chem. Eng. Sci. 2016, 148, 275-281.

[18] Ribeiro, R. P. P. L.; Camacho, B. C. R.; Lyubchyk, A.; Esteves, I. A. A. C.; Cruz, F. J. A. L.; Mota, J. P. B. Experimental and computational study of ethane and ethylene adsorption in the MIL-53(Al) metal-organic framework. Microporous Mesoporous Mater. 2016, 230, 154-165.

[19] Pires, J.; Pinto, M. L.; Saini, V. Ethane selective IRMOF-8 and its significance in ethaneethylene separation by adsorption. ACS Appl. Mater. Interfaces 2014, 6, 12093-12099.

[20] Böhme, U.; Barth, B.; Paula, C.; Kuhnt, A.; Schwieger, W.; Mundstock, A.; Caro, J.; Hartmann, M. Ethene/Ethane and Propene/Propane Separation via the Olefin and Paraffin Selective Metal-Organic Framework Adsorbents CPO-27 and ZIF-8. Langmuir 2013, 29, 8592-8600.

[21] Gücüyener, C.; van den Bergh, J.; Gascon, J.; Kapteijn, F. Ethane/Ethene Separation Turned on Its Head: Selective Ethane Adsorption on the Metal-Organic Framework ZIF-7 through a Gate-Opening Mechanism. J. Am. Chem. Soc. 2010, 132, 17704-17706.

[22] Hartmann, M.; Böhme, U.; Hovestadt, M.; Paula, C. Adsorptive separation of olefin/paraffin mixtures with ZIF-4. Langmuir 2015, 31, 12382-12389. 
[23] Yoon, T.-U.; Baek, S. B.; Kim, D.; Kim, E.-J.; Lee, W.-G.; Singh, B. K.; Lah, M. S.; Bae, Y.-S.; Kim, K. S. Efficient separation of $\mathrm{C}_{2}$ hydrocarbons in a permanently porous hydrogenbonded organic framework. Chem. Commun. 2018, 54, 9360-9363.

Disclaimer: Certain commercial suppliers are identified in this paper to foster understanding. Such identification does not imply recommendation or endorsement by the National Institute of Standards and Technology, nor does it imply that the materials or equipment identified are necessarily the best available for the purpose. 